12

\title{
Periglacial environments and frozen ground in the Central Pyrenean high mountain area. Ground thermal regime and distribution of landforms and processes
}

\author{
Enrique Serrano ${ }^{1}$, José Juan de Sanjosé-Blasco ${ }^{2}$, Manuel Gómez-Lende ${ }^{3}$, Juan Ignacio López- \\ Moreno $^{4}$, Alfonso Pisabarro ${ }^{1}$, Adrián Martínez-Fernández ${ }^{1}$ \\ ${ }^{1}$ Department of Geography. University of Valladolid. Plaza del Campus, s/n, 47011 Valladolid; serranoe@ fyl.uva.es. \\ ${ }^{2}$ Department of Graphic Expression. Polytechnic School. University of Extremadura. \\ ${ }^{3}$ PANGEA Research Group, University of Valladolid, Spain Valladolid. \\ ${ }^{4}$ Dept. of Geoenvironmental Processes and Global Change, Instituto Pirenaico de Ecología (CSIC).
}

\begin{abstract}
The periglacial belt is located in the highest parts of temperate mountains. The balance between mean air and ground temperatures and the presence of water determine the effectiveness of periglacial processes related to permafrost, the active layer or seasonally frozen ground (SFG). This work puts together the thermal and geomorphological data obtained in four Pyrenean massifs, Infierno-Argualas, Posets, Maladeta and Monte Perdido, to improve knowledge on the occurrence and distribution of frozen ground. The methodology used is based on the study of landforms as frozen ground indicators, mapping processes, ground temperature analysis, basal temperature of snow, thermal mapping and geomatic surveys on rock glaciers and protalus lobes. In the Pyrenean high mountain areas the lower limit of frozen ground is at $2,650 \mathrm{~m}$ a.s.1., possible permafrost appears above 2,650 $\mathrm{m}$ a.s.1. in $\mathrm{N}$ and $\mathrm{S}$ orientations and probable permafrost is dominant above $2,900 \mathrm{~m}$ a.s.1.. Unfrozen ground with cold-associated geomorphological processes reach $2,900 \mathrm{~m}$ a.s.l. and unfrozen and frozen ground distribution points to a patchy pattern throughout the periglacial belt. The most widespread frozen grounds are SFG. The thermal data -MAGT, cold season temperatures, BTS measurements, freeze/thaw cycles and distribution of landforms permit the establishment of a periglacial land system divided into three main belts: infraperiglacial, middle and supraperiglacial. The large number of processes and landforms that are involved and their altitudinal and spatial organization make up a complex environment that determines the geoecological dynamic of the high mountain areas.
\end{abstract}

Key words: periglacial belts, altitudinal distribution, high mountain, mountain permafrost, Pyrenees.

\section{Introduction}

The periglacial belt of the temperate mountains is located in the highest part of the mountain and the present-day landscape dynamics are dominated by glacial retreat, paraglacial activity and the gradual atmospheric cooling with altitude. The topoclimatic factors results in high-relief slope processes, with characteristic cascade systems that define alpine environments. Snow, water, ice and thermal changes determine surface processes, among which frozen grounds are one of the primordial elements of the periglacial belt of temperate mountains. Mountain permafrost is a complex cryogenic phenomenon defined by instability, high sensitivity to environmental changes and a highly heterogeneous spatial distribution pattern, topography, vertical and lateral variability in the local climate, snow cover distribution and surface and subsurface temperatures ${ }^{1,2,3}$. There is no full agreement on the main factors determining the distribution of frozen ground, seasonally frozen ground (SFG) or permafrost, in the mountains. These maybe either the solar radiation related to snow cover or the 
temperatures decline with altitude, but the relation between the mountain permafrost

46 degradation and the increased air temperature and therefore its vulnerability to climate

47 change has been observed ${ }^{4}$, which raises the importance of knowledge of permafrost

48 distribution.

49 Permafrost mapping is an important tool for gaining knowledge of the state and extent

50 of mountain permafrost and has been applied in many mountain ranges. Permafrost

51 distribution maps have been drawn up based on the combination of field observations and semi-empirical models ${ }^{6,7,8,9,10,11,12}$ and are based on different classifications of permafrost (Table 1). Maps based on spatial classifications are useful for knowing the potential area the mountain permafrost extends to on a regional scale, whereas maps on a local scale are not common since they require evidence of permafrost, geoelectrical and thermal field data and the relationships among factors, applied by modelling ${ }^{20}$.

\section{Table 1}

Frozen ground is highly sensitive to global warming and in this respect there are processes related to the active layer that increase natural hazards in the high mountain areas ${ }^{14,2,5}$. Mountain permafrost gives rise to singular thermal and hydrological

61 conditions that create unique ecosystems. Detailed knowledge of which, in the case of the Pyrenees, would facilitate the incorporation of frozen grounds in the estimate of geodiversity, geoconservation management and resources for geotourism in protected

64 areas and the high mountain.

65 The first contributions on the presence of periglacial landforms and processes in the 66 Pyrenees come from geomorphological studies defining landforms, such as debris talus,

67 nivo-karst, patterned grounds, solifluction lobes and rock glaciers ${ }^{14,15,16,17,18,19}$. Also, the

68 presence of permafrost was confirmed by observation in the field ${ }^{26}$. In the $1980 \mathrm{~s}$

69 significant progress was made in the study of the active periglacial processes through 
70 the analysis of rock glaciers ${ }^{32,21,22,23,24}$, but it was not until the 1990s that studies began

71 to deal with frozen grounds, mainly on mountain permafrost. Their study increased with

72 the application of analysis and mapping of geomorphological indicators, ground thermal

73 records, geophysical surveys, permafrost distribution mapping and the creation of 74 empirical models ${ }^{24,25,26,27,28,29}$ as well as ongoing observation of active periglacial 75 processes ${ }^{29,30,31,32,26,27,29,33,21}$. Pyrenean permafrost was included in the permafrost map 76 of the northern hemisphere ${ }^{49}$. In the 21 st century periglacial processes are still 77 monitored using geomatic techniques and detailed analysis of the activity and 78 distribution of active rock glaciers and permafrost ${ }^{34,36,37,38,39,40,41,13,41,42,43,44}$. Synthetic 79 mapping on a regional scale $\left(1: 300.000^{37}\right)$ uses permafrost indicators (rock glaciers, 80 gelifluction, ice caves, frost mounds, vertical electric soundings and thermal ground 81 recordings), digital terrain models and modelling of basic parameters (Mean Annual Air 82 Temperature -MAAT-, aspect, slope) that determine permafrost using the classification 83 of possible or probable permafrost. These studies established the distribution of 84 permafrost as being possible above 2,400 $\mathrm{m}$ a.s.l. in northern orientations and from $852,650 \mathrm{~m}$ in southern ones, though it may be present as low as 2,000 $\mathrm{m}$ a.s.l. under 86 favourable topoclimatic conditions; probable permafrost above 2,700 $\mathrm{m}$ a.s.l. in 87 northern orientations, whereas on south-facing slopes the lower limit is 2,800 m a.s.1. ${ }^{37}$,

88 42. Similar distributions have also been put forward, with possible permafrost from $892,800 \mathrm{~m}$ a.s.l. and probable from $2,900 \mathrm{~m}$ a.s.l. ${ }^{13}$, or discontinuous permafrost over $902,600 \mathrm{~m}$ a.s.l. on north-facing slopes and 2,850 $\mathrm{m}$ a.s.l. on south-facing slopes ${ }^{45}$.

91 The aim of this work is to put together the thermal and geomorphological data obtained 92 from four Pyrenean massifs to improve the knowledge on the occurrence and 93 distribution of frozen grounds and the altitudinal and morphodynamic definition of the 
94 Pyrenean periglacial belts. In so doing, this research seeks the answers to three basic

95 questions:

96 - How are frozen grounds distributed in the Pyrenees and what importance do they have

97 as elements of the cryosphere?

98 - How important are frozen grounds in the periglacial landsystem of the Pyrenees and

99 what are their key elements, thermal regime, landforms and processes associated?

100 - How do frozen grounds contribute to the morphogenic altitudinal zoning of the

101 Pyrenees and provide a model for the temperate mountain of moderate altitude?

102 3. Study site: The Pyrenees.

103 The Pyrenees is a mountain range located in the north of the Iberian Peninsula (between

$10442^{\circ}$ and $43^{\circ}$ North latitude) which extends over $435 \mathrm{~km}$ (Figure 1). The study was

105 applied in high glacial cirques of four Pyrenean massifs, Infierno (3,175 m a.s.1.), Posets

106 (3,375 m a.s.1.), Monte Perdido (3,355 m a.s.1.) and Maladeta (Aneto peak, 3,404 m

107 a.s.1.) located in the southern side of the central Pyrenees (Figure 2).

108 Figure 1.

109 The collision of the European and Afro-Iberian plates raised the Pyrenees, forming a

110 central core, the axial zone, where the highest altitudes are located, formed by Paleozoic

111 rocks (slates, schist, granites, marble, gneiss, hornfels, skarns and limestones). Two

112 thrust systems were developed to the north and south of the axial zone, the southern one

113 involving cover rock (sedimentary rocks, limestone, marls, sandstones) ${ }^{46,47}$. The

114 Infierno is located in the axial zone, a folded massif of schists, marbles and slates;

115 Posets, at the boundary between the granitic batholith and the contact metamorphism

116 aureole; and Maladeta massif, situated in a wide granitic batholith. The Monte Perdido

117 massif is a part of the Monte Perdido thrust sheet formed by a calcareous fold cascade

118 reaching 3,335 $\mathrm{m}$ a.s.l. All massifs are on the southern slope in the Ebro river basin. 
119 The central portion of the Pyrenees is in a Atlantic-Mediterranean transitional climate

120 defined by the eastward transition from Atlantic to Mediterranean conditions, whose 121 topographic heterogeneity explains the large spatial variability in annual precipitation

122 and temperature distributions. The sites studied are located in the high mountain, where

123 precipitations are $>2,000 \mathrm{~mm} \mathrm{a}^{-1}$ above $2,000 \mathrm{~m}$ a.s.1. and around 2,500 $\mathrm{mm} \mathrm{a}^{-1}$ at the

124 highest points ${ }^{48}$. Summer and winter are relatively dry, with snowfalls alternating with

125 long anticyclonic periods ${ }^{48}$. Temperatures indicate a clear altitudinal gradient. Above

$1261,000 \mathrm{~m}$ a.s.l. the average annual temperature is less than $10^{\circ} \mathrm{C}$ but at $2,000 \mathrm{~m}$ a.s.l. it is

127 around $5^{\circ} \mathrm{C}$. The $0^{\circ} \mathrm{C}$ isotherm varies among the massifs, and has been placed at

128 different altitudes: 2,750 m a.s.1. ${ }^{48}, 2,780-3,000 \mathrm{~m}$ a.s.l. ${ }^{13}$ and 2,950 m a.s.1. ${ }^{49}$.

129 The Pyrenean high mountain occupies around $365 \mathrm{~km}^{2}$, and makes up just $0.83 \%$ of the

130 total surface, which ranges from $2,400 \mathrm{~m}$ a.s.l to $3,404 \mathrm{~m}^{50,13}$. It is a rocky high

131 mountain environment dominated by the periglacial belt and just 19 small glaciers and

132 ice patches ${ }^{51}$, all of which are located in glacial cirques, all beneath summits of over

133 3,000 $\mathrm{m}$ a.s.l. The four studied massifs still contain active glaciers, four in Maladeta,

134 two in Posets, one in Infierno and one in Monte Perdido ${ }^{49,51,52}$.

135 Glaciers shaped the High Pyrenees during the Pleistocene glaciations, through glaciers

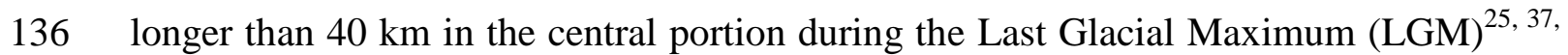

$137 \quad 35,52$. Features of the Dryas period are very important, and at least two stages with small

138 glaciers shaped the highest cirques in the Late-glacial ${ }^{27,53,54,55}$. In the Little Ice Age

139 (LIA) glaciers occupied cirques and fashioned moraine complexes ${ }^{56,27,57,58}$. Paraglacial

140 and periglacial environments have occupied the high mountain for the last $12 \mathrm{ka}^{52}$, so all

141 massifs studied have LIA moraine complexes and are in occupied areas by Dryas period

142 moraine systems (Figure 2).

143 Figure 2. 


\section{3. Material and methods}

145 The study of frozen grounds and related geomorphic processes have been made using

146 different techniques such as geomatic surveys, continuous dataloggers, bottom

147 temperature snow (BTS) measurements and thematic mapping (geomorphological and

148 thermal) in the four studied Pyrenean massifs (Table 2). Previously published data are

149 the BTS measurements of the Posets massif ${ }^{59}$ and measures on rock glacier dynamic,

150 displacement and thinning $30,36,60,61$, where new data from years after 2011 have been

151 incorporated.

152 Table 2

153 - Landforms and mapping processes. Four geomorphological maps of Infierno, Posets,

154 Maladeta and Monte Perdido have been made on a $1 / 10,000$ scale, on which all

155 periglacial and active processes are represented. All of them are based on the

156 Numerical Cartographic Base 1:25,000 (BCN25) of the National Topographic Map

157 (MTN25). For the field work a digital terrain model (MDT) at $5 \mathrm{~m}$ resolution and aerial

158 photography were used. The graphic representation is based on the symbols and colours

159 assigned to each morphogenetic system $^{62}$, although only periglacial processes and

160 landforms are used as indicators on the maps of frozen ground. The landforms used as

161 indicators of frozen ground were rock glacier, protalus lobes, debris lobes, frost mounds

162 and patterned ground, all of them characteristics of periglacial landsystem ${ }^{63}$. A

163 periglacial landsystem can be defined as the set of processes, landforms and sediments

164 associated with changes in water status and frozen ground in polar, upland or

165 periglacial mountain environments ${ }^{63}$, where the last one can divided in altitudinal belts.

166 - Ground temperatures (GTS): The ground thermal regime was monitored between 2010

167 and 2016 by means of 37 continuous dataloggers (Ibuttons DS1922L and DS1921G)

168 distributed between 2250 and $3070 \mathrm{~m}$ a.s.l. and placed at depths between 2 to $\sim 10 \mathrm{~cm}$, 
169 depending of existing surface formation, in the Infierno (3 units), Posets (5 units),

170 Maladeta (11 units) and Monte Perdido (18 units) massifs. A thermoregister recorded

171 data at four-hour intervals within a thermal range of -40 and $+85^{\circ} \mathrm{C}$ and with a

172 resolution of $\pm 0.5^{\circ} \mathrm{C}$. The data obtained revealed the ground thermal regime so that the

173 evolution and thermal periods of the ground and possible existence of frozen grounds

174 could be established ${ }^{64,65}$.

175 Several parameters were used in this work. The Mean Annual Ground Temperature

176 (MAGT) indicative of the existence of permafrost when ground temperature is $<0^{\circ} \mathrm{C}$

177 throughout the year ${ }^{66}$. The mean cold period ground temperature (MWGT),

178 complementary of the basal temperature of the snow measured in March, is an indicator

179 of the presence of frozen ground when between $<-2^{\circ} \mathrm{C}$ and $<-6^{\circ} \mathrm{C}$, seasonal frozen

180 ground (SFG) when temperatures are between $0^{\circ} \mathrm{C}$ and $-2^{\circ} \mathrm{C}$, and freeze-thaw processes

181 and unfrozen ground, when temperatures are at $\sim 0^{\circ} \mathrm{C}$ or moderately negative at -

$1821{ }^{\circ} \mathrm{C}^{89,90}$. The freezing index (FI index) and freeze/thaw cycles facilitate the

183 quantification of the cooling of the ground and are used to indicate the presence of SFG

184 and the geomorphological effectiveness in the top $10 \mathrm{~cm}$ of the ground ${ }^{69}$.

185 - Basal temperature of the snow (BTS) measurements. Over the last ten years the BTS

186 has been measured in March in all the massifs studied, totaling 290 BTS measurements.

187 Two steel probes ( $2 \mathrm{~m}$ length) were used together with a sensor at the tip connected to a

188 RTD thermometer "PHD 2307.0 Delta" with a precision of $\pm 0.2^{\circ} \mathrm{C}$ ( -120 to $\left.200^{\circ} \mathrm{C}\right)$ and

$189 \pm 1{ }^{\circ} \mathrm{C}$ (exterior). Thermal profiles of the snowpack were made in all studied areas to

190 know the thermal structure and changes in snow depth. BTS is a very common

191 technique for the detection of permafrost conditions in the ground and it has been

192 shown to be a useful method for the indirect detection of permafrost ${ }^{6,67,70}$. Some studies

193 have demonstrated a high dependence of BTS measurements on the characteristics of 
194 the snow cover itself $^{71}$ and some dysfunctions in locating permafrost by applying 195 geophysical techniques and BTS ${ }^{72}$. BTS measurements are commonly used to determine 196 ground surface temperatures and to identify areas of homogeneous thermal 197 behaviour $^{70,72}$. The technique is especially useful when the measurement between snow 198 and ground can be compared with GTS obtained by continuous dataloggers.

199 - Thermal mapping. Four thermal maps have been made in the studied areas ${ }^{41,13}$ at $2001 / 10,000$ scale. Thermal maps represent the thermal conditions of the grounds according to GTS and BTS measurements and include information deriving from landforms and processes as indicators. The four maps show the distribution pattern of frozen grounds and probable permafrost, possible permafrost, SFG and unfrozen ground. Thermal data

204 and frozen ground indicators were integrated with GIS techniques ${ }^{37,73}$. A DEM that 205 integrates data of altitude, slope, orientation and exposure and the annual solar radiation 206 rate to know the effects of the topoclimatic factors ${ }^{73}$, thermal information (BTS and

207 GTS), the $0^{\circ} \mathrm{C}$ and $-2^{\circ} \mathrm{C}$ isotherms, and the indicative landforms of SFG or mountain 208 permafrost in the Pyrenees (rock glaciers, protalus lobes, debris lobes, frost mounds, 209 patterned ground) were added.

210 - Geomatic surveys. At sites of frozen ground at different altitudes, surface 211 displacement was monitored by GPS-RTK and Terrestrial laser scanner (TLS) ${ }^{74,13,75}$.

212 Measurements were made on rock glaciers, protalus lobes and debris lobes. Innovation 213 in geomatic techniques has reduced the logistical effort and costs, and raised the quality 214 of the data ${ }^{76}$. The GPS-RTK techniques were applied by monitoring points distributed 215 over the surface of the frozen bodies ${ }^{77,74}$ and led to an accuracy of around $\pm 2 \mathrm{~cm}$. The 216 TLS were used for the precise monitoring of rock glaciers and debris lobes ${ }^{76}$ in order to 217 observe vertical and horizontal changes with accuracy of $\sim 1-3 \mathrm{~cm}$. A scanning net is 218 first obtained, which leads to the construction of a triangular irregular net (TIN) and a 
219 DEM is finally built, from which annual spatial losses or gains in volume can be 220 calculated $^{74}$.

221 - Altitudinal belts. Finally, the altitudinal relations between landforms indicator of SFG,

222 the thermal regime and annual medium temperatures, the winter temperatures obtained

223 by continuous dataloggers and BTS, and thermal maps information permitted us to

224 establish the periglacial belts at the Pyrenees. In Europe periglacial belts have been 225 established by Chardon ${ }^{78}$ and Lehmkuhl $^{79}$ in the Alps, Sellier ${ }^{80}$ in the European Atlantic 226 mountains, and Lehmkuhl ${ }^{79}$ in the Eurasian mountain (Tienshan, Altai, Khangay and

227 Verkhoyansk). This studies have always relied on periglacial landforms, processes and 228 permafrost features, and now thermal data are included to estimate the altitudinal range 229 of periglacial belts.

\section{4. Results}

\section{$231 \quad 4.1$ Landforms and mapping processes}

232 Periglacial active processes in the central Pyrenees were detected in all Pyrenean high 233 mountain areas (Table 3), where a periglacial environment defines the morphogenetic 234 system. Periglacial processes exist at any altitude in the studied areas, and those related 235 to nivation, the freeze/thaw cycle, frost cracking, solifluction and mass wasting were 236 mapped from 2,200 $\mathrm{m}$ a.s.l. Nivation and frost cracking were found to be the most 237 common processes from 2,200 $\mathrm{m}$ a.s.1. to 3,300 $\mathrm{m}$ a.s.l. This is significant, as it permits 238 the most developed geoecological belts in the Pyrenean high mountain to be classified 239 as nivo-periglacial, where nivation processes are dominant, and cryonival, when 240 gelifraction and frozen grounds prevail.

\section{Table 3}

242 The geomorphic processes related to frozen ground are represented in a wide altitudinal 243 rangue between $2,500 \mathrm{~m}$ a.s.l. to the west and 2,910 $\mathrm{m}$ a.s.l. to the east. A west-east 
244 gradient can be appreciated at the lower limit of processes related to frozen ground

245 (Figure 3). Patterned ground, solifluction lobes and rock glaciers have a west-east 246 gradient from $200 \mathrm{~m}$ to over $300 \mathrm{~m}$ respectively, while the gradient in frost mounds,

247 protalus lobes and patterned ground shows more variability on the eastern side. The

248 upper limits conserve the same tendency but the different altitudes, locations with flat

249 topographies and summit crest development determine the upper limit of frozen

250 grounds.

251 Figure 3

252 Landforms as an indicator of frozen ground are scattered throughout the high mountain 253 above $\sim 2,590 \mathrm{~m}$ a.s.l. Rock glaciers, protalus lobes and frost mounds are the most useful 254 indicators of frozen bodies and permafrost. Debris lobes and patterned ground indicate 255 the existence of ice on the ground, but not necessarily permanently frozen ground. 256 There are four rock glaciers and eight protalus lobes in the studied areas, all located 257 between 2,590 and 3,100 $\mathrm{m}$ a.s.l. The fronts of rock glaciers are at different altitudes 258 depending on topography, historical evolution and topoclimatic factors, but in all cases 259 their roots are located above $3,000 \mathrm{~m}$ a.s.l. They are landforms inherited from past 260 conditions. In the case of Argualas they date from the Holocene, while in Posets they 261 are at least pre-LIA ${ }^{36,61}$. They show degradation features in the lower part of the tongues 262 but, together with protalus lobes, they are the only permanent frozen bodies that flow 263 downhill. From $\sim 2,670 \mathrm{~m}$ a.s.l. protalus lobes and frost mounds develop, both related to 264 the existence of permafrost. Processes are distributed according to altitude: in lower 265 areas nivation, gelifraction and mass wasting are dominant, while from $\sim 2,500 \mathrm{~m}$ a.s.1. 266 geomorphic processes related to SFG develop, and above $\sim 2,750 \mathrm{~m}$ a.s.1. processes are 267 permafrost-related, all of them active up to the highest areas.

\section{4.2. Ground temperatures}


MAGT shows a high positive correlation ( $\mathrm{r}=0.87$ ), indicating cooling of the ground with

270 altitude (Figure 4). MAGT $<0^{\circ} \mathrm{C}$ are found above $2,800 \mathrm{~m}$, and there are no MAGT <-

$2712^{\circ} \mathrm{C}$, which points to the possibility of SFG above 2,650 m. At lower altitudes MAGT

272 between $2^{\circ} \mathrm{C}$ and $6^{\circ} \mathrm{C}$ are dominant. The lack of vegetation and the homogeneous and

273 thin coverage and grain size of sediments, commonly till and debris slope, permit us

274 considerate the orientation, altitude and snow distribution as the main factors

275 influencing the MAGT. From 2,800 $\mathrm{m}$ a.s.l. there is no clear trend and altitude is no

276 longer the determinant factor of ground temperatures. Thereafter, orientation,

277 accumulation and snow melt become the dominant factors in the distribution of frozen

278 grounds, with a broad range of MAGT between $3^{\circ} \mathrm{C}$ and $-1.5^{\circ} \mathrm{C}$, which reflects the

279 presence of all types of grounds, without ice, with seasonal ice or with permanent ice.

280 Figure 4.

281 Mean ground temperatures in March show a lower correlation with altitude $(\mathrm{r}=0,66)$,

282 though they have the same structure as MAGT (Figure 4). This structure is

283 characterized by three behaviours differentiated by altitude: between $2,200 \mathrm{~m}$ and 2,500

$284 \mathrm{~m}$; between 2,500 $\mathrm{m}$ and 2,850 $\mathrm{m}$; and over 2,850 $\mathrm{m}$ a.s.1. (Figure 5A and B).

285 - At the lower altitudes, below 2,500 m a.s.l., winter temperature increases with altitude 286 with the highest correlation $(\mathrm{r}=0.66)$, and the thermal range lies between $3^{\circ} \mathrm{C}$ and $-2^{\circ} \mathrm{C}$.

287 - Between 2,500 $\mathrm{m}$ and 2,850 $\mathrm{m}$ a.s.l. ground cooling with altitude has a lesser gradient 288 and very low correlation $(\mathrm{r}=0.007)$. All records show temperatures $>-2^{\circ} \mathrm{C}$, indicating 289 possible permafrost and SFG. Only one record points to a mean March ground 290 temperature $>2^{\circ} \mathrm{C}$, and this is in the Monte Perdido massif.

291 - From 2,850 $\mathrm{m}$ a.s.l. temperatures show a higher though rather low correlation with 292 altitude $(\mathrm{r}=0.12)$ and a greater thermal gradient. All the temperatures show records 293 below $-2^{\circ} \mathrm{C}$, except one located on the south side of Astazou, and those below $-4^{\circ} \mathrm{C}$ are 
294 dominant $\left(78 \%\right.$ ), with one record $>0^{\circ} \mathrm{C}$. The thermal records clearly show the

295 dominance of permafrost, both possible and probable, though with the presence of SFG.

296 The cold season ground temperature points to the presence of frozen grounds from

297 2,300 $\mathrm{m}$ a.s.l. in La Maladeta, but as a whole they are only dominant between 2,580 $\mathrm{m}$

298 and 2,850 $\mathrm{m}$ a.s.1.

299 Figure 5.

300 Data from GTS and its annual evolution show three ground thermal regimes in the 301 studied massifs: "Thermal regime dependent on atmospheric temperature", "Thermal

302 regimes of grounds dependent on the snow cover" and "Frozen soil thermal regimes".

303 The first type is located at the lower limit, where ground temperature has a high

304 correlation with air temperatures. The second type is characterized by stable cold season

305 temperatures $\left(\sim 0^{\circ} \mathrm{C}\right.$ for 6 to 8 months $)$ and negative temperatures in autumn $\left(0\right.$ to $\left.-3^{\circ} \mathrm{C}\right)$,

306 showing the absence of frozen ground up to $2,785 \mathrm{~m}$. The third type reflects either a

307 long period with ground temperatures below $0^{\circ} \mathrm{C}$ under atmospheric influence, or the

308 presence of permafrost.

309 4.3. Basal temperature of the snow measurements

310 BTS measurements show a certain similarity with the thermal ground records (Figure

311 5). The correlation between altitude and temperature in the ground is lower than

312 observed for ground temperatures $(\mathrm{r}=0,61)$, but a similar pattern can be seen. Ground

313 temperature falls with altitude up to $\sim 2,500 \mathrm{~m}$ and thereafter the thermal range in the

314 ground broadens slightly to go from $\sim 2^{\circ}$ at $2,350 \mathrm{~m}$ a.s.l. to $6.5^{\circ} \mathrm{C}$ at $2,500 \mathrm{~m}$ a.s.1., $8^{\circ} \mathrm{C}$

315 at $2,700 \mathrm{~m}$ a.s.l. and $10.5^{\circ} \mathrm{C}$ at $3,000 \mathrm{~m}$ a.s.l.

316 Above 2,650 $\mathrm{m}$ a.s.l. BTS measurements remain between $0^{\circ} \mathrm{C}$ and $-4^{\circ} \mathrm{C}$ and from 2,700

$317 \mathrm{~m}$ a.s.l. between $0^{\circ} \mathrm{C}$ and $-8^{\circ} \mathrm{C}$. Above 2,650 $\mathrm{m}$ a.s.1. BTS measurements remain between

$3180^{\circ} \mathrm{C}$ and $-4^{\circ} \mathrm{C}$ and from $2,700 \mathrm{~m}$ a.s.l. between $0^{\circ} \mathrm{C}$ and $-8^{\circ} \mathrm{C}$. Above $2,700 \mathrm{~m}$ a.s.l. 
319 records with temperatures $<-2^{\circ} \mathrm{C}$ are dominant $(76 \%)$, and above $2,975 \mathrm{~m}$ a.s.1. $60 \%$ of 320 temperature records are $<-6^{\circ} \mathrm{C}$. Between this altitude and up to $3,020 \mathrm{~m}$ a.s.l. the BTS 321 measurements have a greater thermal range, with ground teperatures between $0^{\circ} \mathrm{C}$ and $3222^{\circ} \mathrm{C}$ (Figure $5 \mathrm{C}$ ). Therefore there is SFG, possible and probable permafrost, and from $3233,020 \mathrm{~m}$ a.s.l. all BTS records are $<-2^{\circ} \mathrm{C}$. Hence, between $\sim 2650$ and $3050 \mathrm{~m}$ a.s.l. there 324 is a patchy spatial pattern of discontinuous permafrost with SFG. This all indicates an environment with continuous permafrost wherever there are no vertical crests, which, above this altitude, only happens at the Monte Perdido, Maladeta and Posets massifs, and only over a small area $(\sim 700 \mathrm{ha})$.

328 The number of freeze/thaw cycles has a low correlation with altitude $(r=0.28)$, so it is 329 not among the factors that drive them (Figure 5D). There are areas with a very low

330 number of freeze/thaw cycles $(<20)$ between 2,200 m a.s.l. and 3,020 m a.s.l. From 331 2,500 m a.s.1., two distinct behaviours are recorded: a very low number of freeze/thaw cycles that reach 3,000 $\mathrm{m}$ a.s.l.; and a gradual increase in freeze/thaw cycles with

333 altitude, which reach a maximum at 2,900 m (300 cycles) before falling away at greater 334 altitude. Above 2,850 m freeze/thaw cycles is highly variable (between 150 and 300).

\section{4.4. Geomatic surveys}

336 The displacement and dynamics of several landforms (four rock glaciers, a protalus lobe 337 and a debris lobe), located in the Infierno-Argualas, Posets and Maladeta massifs, were 338 measured by geomatic techniques. All of them are above 2,700 $\mathrm{m}$ a.s.1., an altitude at 339 which there is permafrost and processes are related to solifluction and permafrost creep.

340 All analyzed landforms show activity with a wide range of displacement between 1 and $34132 \mathrm{~cm} \mathrm{a}^{-174,36,60,61,75}$.

342 Debris lobes are located at 2,760 $\mathrm{m}$ a.s.1 in the Alba cirque, Maladeta massif. The 343 thermal environment is located at the MAAT $0^{\circ} \mathrm{C}$ and MAGT of $0.9^{\circ} \mathrm{C}$. It is a SFG, 
344 frozen for six months from January to June and its thermal regime is determined by

345 snow accumulation (Figure 6). Mass displacements have been measured between 37

346 and $10 \mathrm{~cm} \mathrm{a}^{-1}$, a slow activity related to frozen ground and water availability by snow

347 melt from April to July.

348 Figure 6.

349 The Maladeta protalus lobe $\left(42^{\circ} 38^{\prime} 51^{\prime \prime} \mathrm{N}-0^{\circ} 38^{\prime} 30^{\prime \prime} \mathrm{E}\right)$ is located between 2,850 and $3502,960 \mathrm{~m}$ a.s.l. It is $113 \mathrm{~m}$ in length with a N-NE orientation and characterized by large 351 granite blocks on the surface. It is in the altitudinal zone between $-4^{\circ} \mathrm{C}$ and $-2^{\circ} \mathrm{C}$ MAAT 352 in the possible permafrost belt and the MAGT is $-1.3^{\circ} \mathrm{C}$. The measured displacement of 353 the protalus lobe is between a maximum mean annual displacement of $10.8 \mathrm{~cm} \mathrm{a}^{-1}$ and a 354 minimum of $3.8 \mathrm{~cm} \mathrm{a}^{-1}$. The displacement recorded in the protalus lobe diminishes 355 progressively towards the central area where the slope decreases, and the displacement 356 at the front increases once more, where instability is greater ${ }^{36,75}$. The recorded dynamic defines a periglacial landform with low activity and interannual variations. The Argualas rock glacier $\left(42^{\circ} 46^{\prime} 22^{\prime \prime} \mathrm{N} / 0^{\circ} 16^{\prime} 16^{\prime \prime} \mathrm{W}\right)$ is located between 2,590 and 3,032 $\mathrm{m}$ a.s.1. It is $750 \mathrm{~m}$ long, oriented to the NW and made up of metamorphic blocks

360 and fine sediments organized in furrows and arches of around 1-3 $\mathrm{m}$ depth (Serrano et al. 200647 ). It is in the possible permafrost belt with MAAT around $-1.5^{\circ} \mathrm{C} /-2^{\circ} \mathrm{C}$. Its measured displacement is between $17.7 \mathrm{~cm} \mathrm{a}^{-1}$ and $32 \mathrm{~cm} \mathrm{a}^{-1}$, and rates for the lower 363 part tend to be greater, reaching $40 \mathrm{~cm} \mathrm{a}^{-1} 30,36$.

364 La Paúl rock glacier $\left(42^{\circ} 39^{\prime} 40^{\prime \prime} \mathrm{N} / 0^{\circ} 26^{\prime} 34^{\prime \prime} \mathrm{E}\right)$ is between 2,830 and 2,950 $\mathrm{m}$ a.s.l. It is $365400 \mathrm{~m}$ long, oriented to the $\mathrm{N}$ and made up of granitic and metamorphic blocks with 366 fine sediments organized in arches and eroded by the growth of the La Paúl glacier 367 during the LIA. The rock glacier lies between the probable and possible permafrost 368 belts, with MAAT around $0.73^{\circ} \mathrm{C}$ and BTS measurements of $2.8^{\circ} \mathrm{C}$ at the front and 
369 between $-3^{\circ} \mathrm{C}$ and $-4.6^{\circ} \mathrm{C}$ in the main body. The measured displacement during the last

370 four years is $30 \mathrm{~cm} \mathrm{a}^{-1}$ at the front with velocities between $31 \mathrm{~cm} \mathrm{a}^{-1}$ to $45 \mathrm{~cm} \mathrm{a}^{-1}$ in the 371 central body.

372 The Posets rock glacier $\left(42^{\circ} 39^{\prime} 27^{\prime \prime} \mathrm{N} / 0^{\circ} 26^{\prime} 39^{\prime \prime} \mathrm{E}\right)$ is between 2,830 and 3,000 $\mathrm{m}$ a.s.l.

373 and has a length of $400 \mathrm{~m}$ and is oriented east-north-east. The surface is made up of fine

374 sediments and small blocks of slates and schist, with large blocks scattered on the

375 surface. MAGT is between $-0.5^{\circ} \mathrm{C}$ and $-1.5^{\circ} \mathrm{C}$ and BTS measurements on the rock

376 glacier show temperatures of $-6^{\circ} \mathrm{C}$, though measurements lower than $-3^{\circ} \mathrm{C}$ are the most

377 common, indicating conditions at the lower limit of the permafrost environment. The

378 mean horizontal displacement rates in the central axis and lower part are around $9 \mathrm{~cm} \mathrm{a}^{-}$

379 , and the fastest movements are recorded in the central part where the displacement rate

380 is $10.9 \mathrm{~cm} \mathrm{a}^{-1} 30,60$. Increases in displacement rates are observed from the root to the

381 central area, decreasing towards the front. The rock glacier shows a dynamic

382 characteristic of very low and attenuated activity rock glaciers and has been classified as

383 distinctive of marginal periglacial mountain environments.

384 The Maladeta rock glacier $\left(42^{\circ} 39^{\prime} 19^{\prime \prime} \mathrm{N} / 0^{\circ} 37^{\prime} 37^{\prime \prime} \mathrm{W}\right)$ is located between 2,910 and

$3853,010 \mathrm{~m}$ a.s.l. It has a length of $210 \mathrm{~m}$, is oriented to the $\mathrm{N}$ and is made up of large 386 granite blocks ${ }^{75}$. It is located within the possible permafrost belt with MAAT between -

$3874^{\circ} \mathrm{C}$ and $-2^{\circ} \mathrm{C}$. MAGT is between $-2^{\circ} \mathrm{C}$ and $-6^{\circ} \mathrm{C}$ and BTS measurements on the rock

388 glacier show temperatures between -3.6 and $-8.4^{\circ} \mathrm{C}$ in a permafrost environment

389 determined by atmospheric and ground temperatures. The measured displacement is

390 between $13.8 \mathrm{~cm} \mathrm{a}^{-1}$ and $12 \mathrm{~cm} \mathrm{a}^{-1}$, an active movement showing debris transport with

391 high-relief slope processes in the high mountain cascade system. On the surface the

392 deep hollows and depressions point to permafrost degradation processes.

\section{4.5. Thermal mapping}


394 The maps of the distribution of frozen grounds reveal the differences between the

395 massifs of Infierno and Monte Perdido, where the altitudinal distribution is a patchy 396 pattern, and those of Posets and Maladeta, where the altitudinal gradient determines the

397 distribution of frozen grounds (Figure 7). The patchy pattern shows differences by 398 orientation, with the presence of unfrozen grounds to 2,750-2,800 $\mathrm{m}$ a.s.1. Above 2,650

$399 \mathrm{~m}$ a.s.l. SFGs are common, such that there is a very moderate altitudinal range in which

400 SFGs predominate and there are unfrozen grounds (at 2,625-2,650 $\mathrm{m}$ a.s.l. in northern 401 orientations and at 2,625-2,780 $\mathrm{m}$ a.s.l. in southern ones). In this altitudinal range the 402 presence of processes such as frost-cracking, nivation, solifluction, gelifluction and 403 cryoturbation point to high periglacial morphodynamic effectiveness.

404 Figure 7.

405 Between 2,650 $\mathrm{m}$ and 2,825 $\mathrm{m}$ a.s.l. in northern and 2,780 $\mathrm{m}$ and 2,900 $\mathrm{m}$ a.s.l. in 406 southern orientations the presence of SFG, unfrozen grounds and sporadic permafrost 407 also confers a patch-patterned spatial distribution. Above this altitude discontinuous 408 permafrost is dominant and from 2,900 $\mathrm{m}$ a.s.1. there is potential continuous permafrost 409 from the thermal data, though the geomorphological data show the presence of 410 processes and landforms not associated with frozen grounds. The presence of crests and 411 summit edges without permafrost in their upper regions, which occurs at over 3,000 m 412 a.s.l., leads us to think that the distribution of discontinuous permafrost and SFG 413 reaches the summits (Figure 7). All areas show a wider frozen ground altitudinal range 414 in northern orientations than in southern ones.

415 Overall, the evidence indicates that on northern slopes mountain permafrost is 416 dominant from $2,750 \mathrm{~m}$ a.s.l. to the watershed crests $(3,000-3,100 \mathrm{~m}$ a.s.1.). On southern 417 slopes SFG is dominant in a broad range between $2,600 \mathrm{~m}$ a.s.l. and at the summits $418 \quad(3,000-3,400 \mathrm{~m})$. 


\subsection{Pyrenean periglacial belts and limits.}

420 The Pyrenean periglacial landsystem can be divided into three main belts with 421 systematically characteristic features according to the thermal data -MAGT, cold season temperatures, BTS measurements, freeze/thaw cycles- and landform distributions:

\section{3 - The infraperiglacial belt.}

424 The thermal data show a belt between $\sim 1,800 \mathrm{~m}$ a.s.1. and $\sim 2,500 \mathrm{~m}$ a.s.l. where the

425 MAAT is around $4^{\circ} \mathrm{C}$ and $2.5^{\circ} \mathrm{C}$, with the cold season annual isotherm of $0^{\circ} \mathrm{C}$ located at $1,785 \mathrm{~m}$ a.s..$^{20}$. The $0^{\circ} \mathrm{C}$ isotherm is the thermal indicator of the beginning of the periglacial belt at $\sim 1,800 \mathrm{~m}$ a.s.l. when ice in the ground can be present even though the snowpack protects the ground from atmospheric temperatures. The MAGT is between $2.5^{\circ} \mathrm{C}$ and $6^{\circ} \mathrm{C}$ and the frozen season temperature between $3^{\circ} \mathrm{C}$ and $-0.5^{\circ} \mathrm{C}$ indicating the

430 possibility of freeze/thaw cycles and nivation processes. The BTS measurements show a narrow thermal amplitude, with a maximum of $6.5^{\circ} \mathrm{C}$ (Figure 5C). The thermal regimes are "dependent on atmospheric temperature", with and without snow cover or with thin snow covers; and "dependent on the snow cover", with cold season temperatures stable

434 at around $0^{\circ} \mathrm{C}$ for 6 to 8 months. Negative temperatures only appear in autumn and are generally moderate. Ground insulation by the snow cover indicated the absence of SFG and permafrost. Therefore, there is only unfrozen ground and cold associated processes, though sporadic permafrost was detected at low altitudes, and only above $1,800 \mathrm{~m}$ a.s.l. at exceptional sites related to snow avalanche channels in north-facing aspects ${ }^{81}$.

439 Processes are also highly varied, mainly those associated with nivation and ground 440 freeze-thaw cycles, although there are also solifluction and frost-cracking processes in 441 this belt. The snowpack generates nival pavement, nivokarst landforms (in the Monte 442 Perdido and Posets massifs), and protalus ramparts. Landforms deriving from frost 443 weathering are directly related to air temperature and direct insolation on the substrate 
444 forming debris talus and cones. Finally, solifluction lobes and sheets, and terracettes,

445 the latter with its upper limit at 2,200 $\mathrm{m}$ a.s.1., are very common and allow the lower 446 limit of the periglacial belt to be established.

\section{7 - The middle periglacial belt,}

448 From $\sim 2,500-2,600 \mathrm{~m}$ a.s.l. to $\sim 2,900 \mathrm{~m}$ a.s.l. a dozen thermoregisters show 449 homogenous temperatures with MAGT between $5^{\circ} \mathrm{C}$ and $-1^{\circ} \mathrm{C}$, the MWGT between $3^{\circ} \mathrm{C}$ 450 and $-2^{\circ} \mathrm{C}$, and a thermal rank from BTS measurements between $4^{\circ} \mathrm{C}$ and $8^{\circ} \mathrm{C}$. This belt 451 coincides with the MAAT between $2.5^{\circ} \mathrm{C}$ and $-0.5^{\circ} \mathrm{C}$, and the $0^{\circ} \mathrm{C}$ isotherm is found 452 between 2,750 and 2,950 $\mathrm{m}$ a.s.l. depending on the massifs considered ${ }^{82,13,49}$. Thermal 453 regimes that are dependent on the snow cover and frozen soil regimes are dominant at 454 these altitudes. It is the main domain of SFG, above 2,650 $\mathrm{m}$ a.s.l. and reaching 2,800$4552,900 \mathrm{~m}$ a.s.1., although there is also unfrozen ground up to 2,750-2,800 $\mathrm{m}$ a.s.l. and 456 permafrost above $2,650 \mathrm{~m}$. Discontinuous permafrost occurs predominantly in the 457 highest part of the belt, appearing over 2,760 $\mathrm{m}$ a.s.l. On the other hand, on the crests, 458 walls and mountain passes topoclimatic conditions are not favourable to permafrost, as 459 is common in alpine models ${ }^{2}$.

460 In the middle periglacial belt there are processes related to frozen as well as unfrozen 461 ground. Cryoturbation is an important indication of continuous or seasonal frozen 462 ground, although frost mounds are not very common in the Pyrenees ${ }^{36,45,83,13}$ and 463 patterned grounds, developing from 2,530 $\mathrm{m}$ a.s.1. to 3,050 $\mathrm{m}$ a.s.1., are not necessarily 464 related to frozen ground. Rock glaciers and protalus lobes are only found on slopes with 465 northern orientations.

\section{6 - The supraperiglacial belt.}

467 The upper belt is developed above $2,900 \mathrm{~m}$ a.s.l. The MAAT is between $-1^{\circ} \mathrm{C}$ and $-2^{\circ} \mathrm{C}$, 468 and the $-2^{\circ} \mathrm{C}$ isotherm is between $3,130 \mathrm{~m}$ a.s.1. and 3,360 $\mathrm{m}$ a.s.l. depending on the 
massifs considered ${ }^{13,49}$, in nearly all cases above the summits. The MAGT is between

$470 \quad 3^{\circ} \mathrm{C}$ and $-1.5^{\circ} \mathrm{C}$, and the cold season temperature between $0.5^{\circ} \mathrm{C}$ and $-8^{\circ} \mathrm{C}$. The BTS

471 temperatures show a thermal rank around $10^{\circ} \mathrm{C}$ always with temperatures below $0^{\circ} \mathrm{C}$.

472 The thermal regimes in the belt are varied. The least represented is the "Thermal

473 regimes of grounds dependent on atmospheric temperature", which only occurs at the

474 highest altitudes above 3,000 $\mathrm{m}$ a.s.l. The high correlation with air temperatures is

475 triggered by windy conditions that clear the snow cover from the ground. The "Thermal

476 regimes of grounds dependent on the snow cover" occur in the lowest part of the belt,

477 which points to permafrost not being present and the insulation of the ground by the 478 snow cover. Finally, the most widespread is "Thermal regimes of frozen grounds", 479 influenced by air temperatures, the presence of permafrost and the arrival of the cold 480 wave from the ground, but this thermal regime also points to the occurrence of SFG.

481 The SFG is very scattered and discontinuous permafrost is dominant, although the 482 thermal conditions of crests, walls and summits prevent the development of continuous 483 permafrost on massifs lower than $3,330 \mathrm{~m}$ a.s.1. There is frost-cracking and nivation at 484 these altitudes, but the dominant processes are permafrost creep, solifluction and 485 cryoturbation. A wide range of landforms are present, but the commonest are the 486 subtract outcrop together with protalus lobes and rock glaciers on the slopes and 487 patterned ground and frost mounds in flat areas.

488 5. Discussion on processes and thermal distribution.

489 Data from the four studied areas show a complex topography with geomorphic 490 altitudinal belts and a patchy pattern of frozen grounds, factors which are consistent 491 with the occurrence of permafrost and $\mathrm{SFG}^{84,2}$. 
492 The four massifs analyzed are fairly homogenous in their behaviour, with differences

493 related to their differing altitudes rather than to geographical or local climate issues. All

494 of them point to general conclusions for the entire Pyrenean mountain range.

495 Snow is the main morphodynamic factor in the Pyrenean periglacial belt since it 496 determines water availability, freeze/thaw cycles and the thermal regime of grounds, 497 mainly in the lower parts of periglacial environments. The moderate activity and high 498 variability of freeze/thaw cycles is due to the atmospheric thermal regime at low 499 altitudes, where it does not cool often below $0^{\circ} \mathrm{C}$, and to the accumulation and duration 500 of the snow cover at the higher ones, as it protects the ground from freeze periods from 501 early autumn to summer. The existence of a high number of freeze/thaw cycles $(>120$ 502 and up to 200) at low altitudes indicates the importance of topoclimatic factors.

503 The periglacial landforms, patterned ground, debris lobes and sheets, are always 504 scattered across areas with water availability in periods without nival protection and the 505 periglacial dynamic is changeable due to the high interannual variability of the 506 snowpack, steered by the complex interactions among climate, topography and blowing 507 snow $^{120}$. Annual snow accumulation and snowpack duration clearly show sensitivity to 508 warming and in the central Spanish Pyrenees both will decrease dramatically over the 509 next century by up to $78 \%$ of the maximum accumulated snow water equivalent, while 510 the duration of the snow cover may shorten significantly at low altitudes ${ }^{85}$. The 511 warming influence on the snowpack decreases with increasing altitude, although 512 changes in the dynamic of the snowpack will be greater on those slopes that received 513 intense solar radiation, those of the $\mathrm{S}, \mathrm{SE}$ and $\mathrm{SW}^{85,86}$. This is of significance to the near 514 future as the effectiveness of periglacial processes in the lower areas as well as the 515 higher ones can be assumed to increase as a result of permafrost degradation. 
516 These records place them within the frame of displacements commonly found in

517 protalus lobes ${ }^{87,36,60}$. In all cases, protalus lobe displacements are slower than those of 518 active rock glaciers.

519 In the Central Pyrenees the main areas with unfrozen grounds reach 2,750-2800 m a.s.1., 520 even though there are SFG above 2,650 $\mathrm{m}$ a.s.l. The altitudinal range of SFG and 521 unfrozen grounds is therefore only between 2,600 and 2,880 $\mathrm{m}$ a.s.1. in southern 522 orientations and in the upper belts SFG and permafrost are dominant, though there are 523 also unfrozen grounds on crests and peaks. At these altitudes there is high periglacial 524 efficiency in generating landforms deriving from the interrelationships between diverse 525 processes such as frost-cracking, nivation, creep and cryoturbation. Also, the 526 geophysical surveys showed evidence of frozen bodies above 2,590 m a.s.1. ${ }^{33,59,34,36,37,39}$, 527 and sporadic permafrost at exceptionally low altitudes, as in the Telera massif, at around $528 \quad 1,850-2,000 \mathrm{~m}$ a.s.1. ${ }^{88}$.

529 The previous data points to a complex spatial thermal distribution, a patchy pattern, in 530 which all kinds of thermal conditions on the ground appear between 2,650 and 2,800 m 531 a.s.l. in northern orientations, and between 2,800 $\mathrm{m}$ a.s.l. and 2,900 $\mathrm{m}$ a.s.l. in southern 532 ones (Figure 8). Discontinuous permafrost is dominant between 2,750 $\mathrm{m}$ a.s.1. and 2,900 $533 \mathrm{~m}$ a.s.l. in northern aspects, but between 2,850 $\mathrm{m}$ a.s.1. and 2,950 $\mathrm{m}$ a.s.1 in the southern 534 faces where the altitudinal range is reduced.

535 The altitudinal range of frozen grounds is always lesser in southern orientations that in 536 northern ones. The most sensitive to current changes by permafrost degradation 537 environment is found at above $3,050 \mathrm{~m}$ a.s.l. There is potential thawing due to the 538 increase in atmospheric temperatures and the altitudinal rise of isotherms disturbing 539 walls and crests. As common in alpine models, the crests, walls and mountain passes 540 topoclimatic conditions are not favourable to permafrost, and natural hazards are 
541 increased $^{2}$, as this also occur in the Pyrenees ${ }^{86,89,52}$. They are no such environments in

542 the Infierno massif because of its lower height, but the area of permafrost is very 543 considerable in Aneto-Maladeta, the Posets massif and Monte Perdido, where more than 544300 ha, 160 ha and 180 ha respectively are located above 3,000 m, all of them highly

545 frequented during summer.

$546 \quad$ Figure 8.

547 Continuous permafrost may occur above 3,000 $\mathrm{m}$ a.s.1., but the summit crests and edges 548 are not favourable to frozen ground development due to the high solar radiation on both 549 slopes $^{90,2}$. As in the Alps, summit areas in the Pyrenees probably have a patchy pattern 550 with SFG and permafrost.

551 The altitudinal organization of periglacial processes and landforms seems to be a sign of 552 a well-established periglacial landsystem in the Pyrenean high mountain. In the 553 mountains the periglacial landsystem has been divided into belts or sub-belts in which 554 the altitudinal range directs dynamic changes and MAAT has been used to delineate the 555 altitudinal belts with permafrost and active processes ${ }^{91,80,79,13}$. The geomorphic 556 periglacial belts included in the periglacial mountain landsystem are of great 557 geoecological interest in the development of functioning models of high mountain 558 environments, ecological relationships and forecasting human-induced or climate 559 changes in the environment.

560 Periglacial belts and limits in European mountains have been established since 561 Chardon $^{78}$ proposed a division in the western Alps between the "infraperiglacial" belt 562 ( 1800-2400 $\mathrm{m}$ a.s.1.), the "periglacial-type" belt ( 2400-3100 $\mathrm{m}$ a.s.1.), and the 563 "supraperiglacial" belt ( 3100-4000 m a.s.1.). These were later simplified and divided 564 into two sub-belts: the inner periglacial sub-belt, defined by the lower limit of active 565 solifluction between 2,200 and 2,350 $\mathrm{m}$ a.s.1., and the upper periglacial sub-belt, 
566 dominated by blockfields, patterned ground, bare bedrock, rock glaciers and solifluction

567 with permafrost environments, at altitudes above 2,400-2,500 m a.s.1. ${ }^{79}$. Lower limits

568 were indicated by Sellier in the Atlantic mountains defined by the lowest solifluction

$569 \operatorname{limit}^{80}$ and in the Rondane massif (Norway) where three periglacial belts were

570 differentiated, all with sporadic to continuous permafrost occurrence ${ }^{192,93,94}$. Several

571 proposals have been made to divide the periglacial belt in the Pyrenees, all of which

572 have distinguished three or four belts (Table 4).

573 Table 4

574 The periglacial belts in the Pyrenees are divided into three units, the infraperiglacial belt

575 ( 1,800 to $\sim 2,500 \mathrm{~m}$ a.s.1.); the middle periglacial belt $(\sim 2,500-2,600$ to $\sim 2,900 \mathrm{~m}$ a.s.l);

576 and the supraperiglacial belt (above 2,900 $\mathrm{m}$ a.s.1.). The infraperiglacial belt was

577 defined by Serrano et al. ${ }^{95}$ and González-García ${ }^{13}$, though the upper limit is now at

578 lower altitudes due to the high ground temperatures, which are always above $2^{\circ} \mathrm{C}$. It

579 includes the nival and nivoperiglacial belts ${ }^{13}$ and the subnival and nival belts ${ }^{135}$ because

580 distinctions are not made by nivation processes and there is no evidence of different

581 thermal regimes. More thermal data and dynamic knowledge on activity and inherited

582 elements are necessary to subdivide the infraperiglacial belt. The middle periglacial belt

583 is located at lower altitude than the "periglacial" and "periglacial-type" previously

584 proposed $^{95,13,96}$, in which the dominance of frozen ground (SFG and permafrost) implies

585 a lowering of the upper and lower altitudinal limits. The supraperiglacial belt is in

586 agreement with the supraperiglacial belt proposed by Serrano et al. ${ }^{95}$ and González-

587 García $^{13}$, though the lower limit has now been set $200 \mathrm{~m}$ lower because of the new

588 recording at 2,900 $\mathrm{m}$ a.s.l. The winter season ground temperatures at this altitude are lower than $-6^{\circ} \mathrm{C}$ and are close to those of permafrost related landforms. 
590 The current active periglacial environments in Iberian mountain ranges are located in

591 the upper parts of the highest mountain ranges and are mostly related to seasonal frost 592 dynamics $^{58}$. Marginal permafrost conditions have only been detected in sporadic 593 patches close to the summits of Sierra Nevada and the Cantabrian Mountains and are 594 related to LIA moraine complexes, today undergoing a rapid degradation of permafrost.

595 At the same altitude as in the Pyrenees, seasonal frost has been detected in the high 596 parts of the Central Range, NW Ranges and the Cantabrian Mountains ${ }^{42}$. The complexity of the periglacial belt in the Pyrenees is not found in other mountains of the Iberian Peninsula. The most common processes are solifluction, characterized by very 599 slow deformation rates (less than $1 \mathrm{~cm} \mathrm{yr}^{-1}$ ), needle-ice activity and miniature patterned 600 ground, all associated with diurnal frost cycles $^{42}$. Nival processes are also common in 601 the Iberian Mountain, and the Pyrenees is no exception. The occurrence of seasonal 602 frozen ground and mountain permafrost in the Iberian Peninsula seems, nevertheless, to

603 be limited by altitude, and only the Pyrenees and Sierra Nevada reach altitudes that 604 support cold environments. Between the two ranges the latitudinal difference is 605 appreciated in the altitudinal distribution of periglacial processes, with frozen ground 606 around $200 \mathrm{~m}$ higher. Only in the Pyrenees are there well developed frozen bodies such 607 as rock glaciers and protalus lobes, which define the Iberian high mountain. Changes 608 related to warming will have significant consequences in the periglacial belt of the 609 Iberian mountains, largely driven by changes in snow depth, spatial variability 610 associated with variations in surface runoff, in soil thermal regimes, and 611 geomorphological processes ${ }^{86,42,52}$.

612 Within the Mediterranean framework permafrost conditions generally increase with 613 altitude towards the eastern part of the region and from north to south ${ }^{43}$. In the western 614 and central Mediterranean, permanently frozen ground is rarely found below 2,500 m, 
615 discontinuous permafrost is generally detected between 2,500 and 2,800-3,000 m and

616 continuous permafrost is distributed in ice-free environments above this level ${ }^{43}$. The

617 altitudinal range observed in the Pyrenees, above 2,600 $\mathrm{m}$ in northern aspects and 2,800

$618 \mathrm{~m}$ in southern ones, is higher than in the southern Alps (above 2,400 $\mathrm{m}$ ) and Rila

619 mountains (above $\sim 2,350 \mathrm{~m}$ ), but lower than in the southeastern ones, such as Mount

620 Olympus, $\sim 2,700 \mathrm{~m}$, NE Turkey and central Anatolia, above $2,800 \mathrm{~m}^{97,98,99}$. To the

621 south permafrost is only found in sporadic patches above $3,000-3,100 \mathrm{~m}$ in Sierra

622 Nevada and the Atlas ${ }^{100,101}$. Latitude seems to be the most determinant factor in the

623 distribution of Mediterranean periglacial belts for massifs of similar altitudes.

624 Oliva et al. $^{42}$ have pointed out that in the near future periglacial activity in Iberian 625 mountains will become restricted to higher elevations. Furthermore, the pronounced 626 future annual and seasonal climate projections would lead to an ascent of permafrost 627 conditions and rapid degradation process, possibly triggering large slope and mass 628 wasting processes with important socio-economic impacts, which have already begun in 629 the Pyrenees ${ }^{43,52}$.

\section{6. Conclusions}

631 The central Pyrenean high mountains offer a broad periglacial belt in which significant 632 morphodynamic variations can be seen. The lower limit of frozen grounds is at $\sim 2,650$ $633 \mathrm{~m}$ a.s.1., although below this level there may be sporadic permafrost or SFG depending 634 on local factors such as topography, slope morphology, aspect, hydrology or thickness 635 and duration of the snow cover. Possible permafrost appears above 2,650 $\mathrm{m}$ a.s.l. in 636 northern and southern orientations and probable permafrost is dominant above 2,900 m 637 a.s.l., but unfrozen grounds reach 2,900 $\mathrm{m}$ a.s.l. as do frozen grounds. The distribution 638 of unfrozen and frozen grounds points to the presence of a patchy pattern throughout the 639 periglacial belt. 
640 The thermal data reveal that the most widespread frozen grounds in the temperate high

641 mountain of the Pyrenees are SFG, which alternate with unfrozen grounds at the lowest

642 altitudes, where the snowpack is the most important element. The snow cover, its

643 thickness and duration determine thermal processes, such as the freeze/thaw cycles on

644 the ground, frost and thermal regimes, and geomorphic ones, such as nivation, the most

645 extended morphogenetic system expressed in a varied representation of landforms such

646 as nival pavements, nivation hollows, nivation dolines and lapies, protalus ramparts,

647 supra-snowpack and sub-snowpack small mudflows, or avalanche snow cones and 648 paths.

649 The degradation of the permafrost is visible in rock glaciers and protalus lobes, as well 650 as on the walls, crests and summits, which indicates an increase in the probability of 651 rock-falls and slope slides over $3,000 \mathrm{~m}$ a.s.l. This is a narrow altitudinal margin of 652 moderate extension, but is highly visited on the most attractive summits (Maladeta653 Aneto, Posets, Monte Perdido massifs), which increases risk. It is also possible to 654 foresee changes to the lower parts related to changes in the duration and thickness of the 655 snow cover, which means an increase in the activity of periglacial processes in the 656 lowest and highest parts of the periglacial belt in the near future.

657 The high mountain area can be divided into periglacial geomorphic sub-belts: the 658 infraperiglacial belt, the middle periglacial belt, and the supraperiglacial belt. The most 659 developed one is the lowest, which has the greatest altitudinal range and surface area, 660 though it is the least active due to the atmospheric thermal conditions between the $4^{\circ} \mathrm{C}$ 661 and $2.5^{\circ} \mathrm{C}$ isotherms and the protective factor of snow cover on the ground. The middle 662 periglacial belt is the most geomorphologically active as it contains all kinds of thermal 663 behaviours in the ground: unfrozen, SFG and mountain permafrost; generating a 664 combination of geomorphological processes and a great capacity for erosion and 
665 transport. The upper belt possesses a highly variable altitudinal amplitude among the 666 different massifs due to the varying altitude of its summits. Although the processes and 667 landforms involved are fewer and simpler in their behaviour than those of the lower 668 belts, it is the most active belt due to its topography, dominated by steep slopes, 669 topoclimatic conditions, location above the $0^{\circ} \mathrm{C}$ isotherm, a highly irregular snow cover 670 in windy areas and degradation of permafrost.

671 The large number of processes and landforms that are involved and their altitudinal and 672 spatial organization make up a complex environment that determines the geoecological

673 dynamic of the high mountain. For this reason and because most of the periglacial high 674 mountain forms a part of the Natural Protected Areas of the Spanish State or the 675 Autonomous Community of Aragon, they must be considered in order to understand 676 high mountain ecosystems and habitats. In particular, changes occurring in the near 677 future associated with projected changes in temperature and precipitation are likely to 678 have a significant influence on high mountain snow cover and permafrost.

679

680 Acknowledgements

681

682 This research has been funded by I+D+I projects CGL2015-68144-R and GL2017-

683 82216-R (MINECO of Spanish government-FEDER).

684

685 References

686

687 1. Nöetzli J, Hoelzle M, Haeberli, W. Mountain permafrost and recent Alpine rock-fall 688 events: a GIS-based approach to determine critical factors. In: Proceedings of the Eighth International Conference on Permafrost. Zürich: Balkema; 2003 :827-832. 
690 2. Haeberli W, Noetzli J, Arenson L. Mountain permafrost: Development and 691 challenges of a young research field. J Glaciol. 2010; 56 :1043-1058. 692 doi:103189/002214311796406121.

693

3. Dobinski W. Permafrost The contemporary meaning of the term and its consequences. Bull Geogr-Phys Geogr Ser. 2012; 5 :29-42.

4. Harris C, Vonder-Mühll D, Isaksen $\mathrm{K}$ et al. Warming permafrost in European mountains. Global Planet Change. 2003; 39 :215-225.

5. Kellerer-Pirklbauer A, Lieb GK, Schoeneich P, Deline P, Pogliotti P. (eds.). Thermal and geomorphic permafrost response to present and future climate change in the European Alps PermaNET project, final report of Action 53. Website. http://wwwpermanet-alpinespaceeu/archive/pdf/WP5_3_final_ reportpdf. Accessed September 20, 2018, 2011.

702

6. Haeberli W. Special aspects of high mountain permafost methodology and zonation in the Alps. In: Proceedings of Third International Conference on Permafrost. National Research Council of Canada: Ottawa; 1978: 378-384. Periglacl Process. 1992; $3: 133-138$.

8. Hoelzle M, Haeberli W, Keller F. Application of BTS-measurements for modelling 709 mountain permafrost distribution. In: Proceedings of Sixth International Conference on Permafrost. Beijing: South China University of Technology Press; $1993: 272-277$.

9. Hoelzle, M. \& Haeberli, W. Simulating the effects of mean annual air temperature changes on permafrost distribution and glacier size: an example from the Upper Engadin, Swiss Alps. Ann Glaciol. 1995; 21 :399-405. 
715 10. Keller F, Frauenfelder R, Gardaz JM, et al. Permafrost map of Switzerland. In:

716 Proceeding Seventh International Permafrost Conference. Yellowknife: Université de Laval; 1998 :557-562.

11. Heginbottom, JA. Permafrost mapping: a review. Prog Phys Geogra. 2002; 26 :623 642.

12. Vonder-Mühll D, Hauck C, Gubler H. Mapping of mountain permafrost using geophysical methods. Prog Phys Geogra. 2002; 26(4) :643-660. doiorg/101191/

13. González-García, M. La alta montaña periglaciar en el Pirineo Central Español: procesos, formas y condiciones ambientales. $\mathrm{PhD}$ Thesis, Málaga: Universidad de Málaga; 2013.

14. Nöetzli J, Gruber, S. Transient thermal effects in Alpine permafrost. The Cryosphere Discussions. 2009 ;2(2) :185-224. DOI: 10.5194/tcd-2-185-2008

15. Boyé, M. Gelivation et cryoturbation dans Massifs du Mont-Perdu (Pyrénées Centrales) Pirineos. 1952; 23 :5-27.

16. Monturiol J. Sobre una forma periglaciar descubierta en el macizo de Vallibierna (Pirineo central). Notas y comunicaciones del IGME. 1959; 55 :59-70.

17. Hupé P. A propos des sols polygonaux et striés des Pyrénées. Comté Rendu Societé Geologique de France. 1961; 8 :228-229.

18. Angely, AG. Anciens glaciers dans l'est des Pyrénées centrales. Revue Geographique Pyrénées Sud-Ouest. 1967;38 :5 28.

19. Höllermann P. The periglacial belt of mid-latitude mountains from a geoecological point of view. Erdkunde. 1985; 39 :259 270. 
20. Cazenave-Piarrot F, Tihay JP. Glaciers rocheaux dans les Pyrénées Centrales et Occidentales. Paris: Societé Hydrotechnique de France (section Glaciologie); $1986: 8$

21. Cazenave-Piarrot F, Tihay JP. Eboulis, formations morainiques et glaciers rocheux dans le massifs de L'Ardiden (Pyrenees Centrales). In: Eboulis et environnement géographique passé et actuel. París: Publ Centre Géographie Physique; 1983; 121 138.

22. Hamilton L. The development, age and present status of a rock glacier in the Posets Massif, Spanish Pyrenees. Pirineos. 1988; 131 :43-56.

23. Agudo C, Serrano E, Martinez de Pison E.. El glaciar rocoso activo de los Gemelos en el Macizo del Posets (Pirineo Aragonés). Cuaternario y Geomorfología. 1989; $3: 83-91$

24. Serrano E, Rubio V. El glaciar rocoso activo de las Argualas. Ería. 1989 ;19-20 :195-198.

25. Serrano E. Glacial evolution of the Upper Gállego Valley (Panticosa Mountains and Ribera de Biescas, Aragonese Pyrenees, Spain). Pirineos. 1991 ; 138:83104.

26. Serrano E. Evolución postglaciar de laderas en la alta montaña del macizo de Panticosa (Pirineo aragonés). In: C Cearreta, F Ugarte. eds. The Late Quaternary in the Western Pyrenean region. Bilbao: Universidad del País Vasco; 1992 ;415426.

27. Serrano E. Geomorfología del Alto Gállego (Pirineo aragonés). Zaragoza; Institución Fernando el Católico: 1998.

28. Lampre, F. Estudio Geomorfológico de Ballibierna (macizo de la Maladeta, Pirineo aragonés): modelado glaciar y periglaciar. Zaragoza: CPNA; 1998. 
29. Serrano E, de Sanjosé-Blasco JJ, Silió F, Agudo C. Movimientos superficiales del glaciar rocoso de las Argualas (Pirineo aragonés). Pirineos. 1995; 145-146 :103110.

30. Serrano E, Agudo C, Martínez de Pisón E. Rock glaciers in the Pyrenees. Permafr Periglacl Process. 1999; $10: 101-106$.

31. Marti M, Serrat D. Les glaceres rocalloses pirenenques. Terra. 1995; 25 :24-34.

32. de Sanjosé-Blasco JJ, Agudo C, Serrano E, Silió F. Auscultacion topográfica y estudio fotogramétrico del glaciar rocoso de las Argualas (Pirineo Aragonés):

34. Brown J, Ferrians OJ, Heginbottom JA, Melnikov ES.1998. Circum artic map of Permafrost. International Permafrost Association, Data and Information Working Group Circumpolar Active-layer Permafrost System (CAPS), version 10 CDROM National Snow and Ice Data Center, Boulder, University of Colorado.

35. Serrano E, Agudo C, González-Trueba JJ. La deglaciación de la alta montaña Morfología, evolución y fases morfogenéticas glaciares en el macizo de Posets (Pirineo Aragonés). Cuaternario y Geomorfología. 2002 ;16 (1-4) :111-126.

36. Serrano E, de Sanjosé-Blasco JJ, Agudo C. Rock glacier dynamic in a marginal periglacial high mountain environment: flow, movement (1991-2000) and structure of the Argualas rock glacier. Geomorphology. 2006; 74 :285-296.

37. Serrano E, Morales C, González-Trueba JJ, Martín-Moreno R. Cartografía del permafrost de montaña en los Pirineos españoles. Finisterra. 2009 ;87 :45-54. 
38. Serrano E, de Sanjosé-Blasco JJ, Atkinson A, et al. Protalus lobe dynamic on Pyrenean High Mountain. In: Proceeding III EUCOP, Thermal State of Frozen Ground in a Changing Climate during the IPY. Longyearbyen: IPA-University Center of Svalbard; $2010: 135$.

792

39. Lugon R, Delaloye R, Serrano E, Reynard E, Lambiel C, González-Trueba JJ. Permafrost and Little Ice Age relationships, Posets massif, Central Pyrenees, Spain. Permafr Periglacl Process. 2004; 15 :207-220.

40. Julián A, Chueca J. Permafrost Distribution from BTS Measurements (Sierra de Telera, Central Pyrenees, Spain): Assessing the Importance of Solar Radiation in a Mid-elevation Shaded Mountainous Area. Permafr Periglacl Process. 2007; 18 :137-149.

41. González-García M, Serrano E, de Sanjosé-Blasco JJ, González-Trueba JJ. Dinámica superficial y estado actual del glaciar rocoso de la Maladeta Occidental (Pirineos). Geogra Res Lett. 2011; 32 :81-94.

42. Oliva M, Serrano E, Gómez-Ortiz A, et al. Spatial and temporal variability of periglaciation of the Iberian Peninsula. Quat Sci Rev. 2016 ;137 :176-199.

43. Oliva M, Žebre M, Guglielmin M, et al. Permafrost conditions in the Mediterranean region since the Last Glaciation. Earth Sci Rev. 2018; 185 :397-436.

44. Ventura J. Identificación e inventario de potenciales glaciares rocosos activos en los Pirineos mediante fotointepretación en visores cartográficos $2 \mathrm{~d}$ y $3 \mathrm{~d}$ : primeros resultados. Polígonos. 2016; 28 :95-122.

45. Feuillet T, Sellier D. Observations sur la limite inférieure de l'étage périglaciaire dans les Pyrénées centrales françaises. Environnements périglaciaires. 2008; 15 :59-68. 
812 46. Teixell A. Crustal structure and orogenic material budget in the west central $813 \quad$ Pyrenees. Tectonic. 1998; 17 :395-406.

814 47. Gibbons W, Moreno T, eds. The Geology of Spain. London: The Geological $815 \quad$ Society; 2002.

816 48. López-Moreno, JI. Recent Variations of Snowpack Depth in the Central Spanish 817 Pyrenees Arctic, Antarctic, and Alpine Research, 2005; 37 :253-260.

818 49. López-Moreno JI, Alonso-González A, Monserrat O, et al. Ground-based remote819 sensing techniques for diagnosis of the current state and recent evolution of the $820 \quad$ Monte Perdido Glacier, Spanish Pyrenees. J. Glaciol. 2019; 65 (249) :85-100. doi: 101017/jog201896

822 50. García-Ruiz JM, Alvera B, del Barrio G, Puigdefábregas J. Geomorphic processes above timberline in the Spanish Pyrenees. Mountain Research and Development. $1990 ; 10: 201-214$

825

51 67. Rico I, Izaguirre E, Serrano E, López-Moreno JI. Current glacier area in the Pyrenees: an updated assessment. Pirineos. 2017 ;2 :e29 doi: org/103989/Pirineos 2017172004

52. Serrano E, Oliva M, González-García M, et al. Post-little ice age paraglacial 829 processes and landforms in the high Iberian mountains: a review. Land Degrad Develop. 2018; 29 (11) :4186-4208. DOI: 101002/ldr3171

53. Palacios D, de Andrés N, López-Moreno JI, García-Ruiz JM. Late Pleistocene deglaciation in the upper Gállego Valley. Quat Res. 2015; 83 :397-414. http://dxdoiorg/101016/ jyqres201501010.

834 54. García-Ruiz, JM, Palacios D, González-Sampériz P, et al. Mountain glacier 835 evolution in the Iberian Peninsula during the Younger Dryas. Quat Sci Rev. 
837 55. Serrano E, Martín-Moreno R. Surge glaciers during the Little Ice Age in the

$838 \quad$ Pyrenees. A controversial dynamics. Geogra Res Lett. 2018; 44 :213-244.

839 56. Martínez de Pisón E, Arenillas M. Los glaciares actuales del Pirineo Español. In: La 840 nieve en el Pirineo español. Madrid: MOPU; 1988: 29-98.

841 57. González-Trueba JJ, Martín R, Martínez de Pisón E, Serrano E. Little Ice Age 842 glaciation and current glaciers in the Iberian Peninsula. The Holocene. 2008; 18 $843 \quad: 568-551$

844 58. Oliva M, Ruiz-Fernández J, Barriendos M, et al. The Little Ice Age in Iberian 845 mountains. Earth Sci Rev. 2018; 177 :175-208.

59. Serrano E, Agudo C, Delaloye R, González-Trueba JJ.. Permafrost distribution in the Posets massif, Central Pyrenees. Nor Geogr Tidsskr. 2001; 55 :245-252.

60. Serrano E, de Sanjosé-Blasco JJ, González-Trueba JJ. Rock glaciers dynamics in marginal periglaciar environments. Earth Surf Process Landf. 2010; 35 (11) :1302-1314.

61. Serrano E, González-Trueba JJ, Sanjosé JJ. Dinámica, evolución y estructura de los glaciares rocosos de los Pirineos. Geogra Res Lett. 2011; 37 (2) :145-170.

62. Smith M, Paron, P, Griffiths, J. Geomorphological Mapping, Methods and Applications Chichester: Elsevier Science; 2011.

63. Evans DJA, Ria K, Orton C. Periglacial geomorphology of summit tors on Bodmin 856 Moor, Cornwall, SW England. J Maps. 2017; 13 :342-349. DOI:101080/17445647201 71308283.

64. Ishikawa M. Thermal regimes at the snow-ground interface and their implications for permafrost investigation. Geomorphology. 2003; 52 :105-120. GeoFocus. 2004; 10 :1-240. 
862 66. van Everdingen RO. Frost mounds at Bear Rock, near Fort Norman, NWT, 1975863 1976. Canadian J Earth Sci. 1978; 15 :263-276.

864 67. Haeberli W. Creep of Mountain Permafrost: Internal structure and flow of Alpine 865 Rock Glaciers. Zurich: Eidgenossischen Technischen Hochschule; 1985.

866 68. Schoenich, P. BTS Bottom temperature of snow cover. Guide lines for monitoring.

867 Lausanne: Suisse-IPA; 2011.

868 69. Fengqing J, Zhang Y.. Freezing and thawing Index. In: P Vijay, P Singh, UK 869 Haritashya, eds. Encyclopedia of snow, ice and glaciers. Dordrecht: Springer; $870 \quad 2011: 301$.

871 70. Hoetzle M. Permafrost occurrence from BTS measurements and climatic parameters $872 \quad$ in the Eastern Swiss Alps. Permafr Periglacl Process. 1992; 3 :143-147.

873 71. Lewkowicz AG, Ednie M. Probability mapping of mountain permafrost using the 874 BTS method, Wolf Creek, Yukon Territory, Canada. Permafr Periglacl Process. 875 $2004 ; 15: 67-80$

72. Ishikawa M. Hirakawa, K. Mountain permafrost distribution based on BTS measurements and DC resistivity soundings in the Daisetsu Mountains, Hokkaido,

879 73. Funk M, Hoelzle M. A model of Potential Direct Solar Radiation for Investigating 880 Occurrences of Mountain Permafrost. Permafr Periglacl Process. 1992; 3 :139881 142.

882 74. de Sanjosé-Blasco JJ, Berenguer F, Atkinson ADJ et al. Geomatics techniques 883 applied to glaciers, rock glaciers, and ice-patches in Spain (1991-2012). Geogr Ann Ser A Phys Geogr. 2014; 96 :307-321. doi:10.1111/geoa.12047 
75. González-García M, Serrano E, de Sanjosé-Blasco JJ, González-Trueba JJ. Surface dynamic of a protalus lobe in the temperate high mountain (Maladeta, Western Pyrenees). Catena. 2017; 149 :689-700.

76. Bauer A, Paar G, Kaufmann V. Terrestrial laser scanning for rock glacier monitoring. Permafrost. In: Proceedings Eighth International Conference on Permafrost. Zurich: Balkema Publishers; 2003 :55-60.

77. de Sanjosé-Blasco JJ, Atkinson A, Salvador F, Gómez-Ortiz A. Application of geomatic techniques in controlling of the dynamics and cartography of the Veleta rock glacier (Sierra Nevada, Spain). Zeitschrift für Geomorphologie. 2007; 51 :79-89.

78. Chardon, C. Montagne et haute montagne alpine critères et limites morphologiques remarquables en haute montagne. Rev Géogra Alp. 1984; 72 :213-244.

79. Lehmkuhl F. The Kind and Distribution of Mid-Latitude Periglacial Features and Alpine Permafrost in Eurasia. In: Proceedings of the Ninth International Conference on Permafrost. Fairbanks: University of Alaska Fairbanks; 2008 :0311036.

80. Sellier D. Les limites de l'étage périglaciaire fonctionnel dans les montagnes atlantiques de l'Europe: éléments d'identification à partir de marqueurs morphologiques. Environnements Périglaciaires. 2006; 13 :41-59.

81. Chueca J, Julián A. Relationship between solar radiation and the development and morphology of small cirque glaciers (Maladeta Mountain Massif, Central Pyrenees, Spain). Geogr Ann Ser A Phys Geogr. 2004; 86A :81-89.

82. del Barrio G, Creus J, Puigdefábregas J. Thermal Seasonality on The High Mountain Belts of the Pyrenees. Mountain Research and Development 1990; 10 (3) :227-233 
910 83. González-García M, Serrano E, González-Trueba JJ. Morfogénesis, morfodinámica

911 y caracterización térmica de montículos de hielo en Los Pirineos (macizos de $912 \quad$ Maladeta y Posets). Polígonos. 2016; 28 :73-93.

913 84. Gruber S, Haeberli W. Mountain Permafrost. In: Permafrost Soils. Chichester:

$914 \quad$ Wiley; $2009: 3-44$.

915 85. López-Moreno JI, García-Ruiz JM, Beniston M. Environmental Change and water 916 management in the Pyrenees. Facts and future perspectives for Mediterranean 917 mountains. Global and Planetary Change. 2008;61 (3-4) :300-312. doi: 101016/jgloplacha200710004

86. López-Moreno JI, Pomeroy J, Revuelto J, Vicente-Serrano SM. Response of snow processes to climate change: spatial variability in a small basin in the Spanish Pyrenees. Hydrol Process. 2013 ;27 (18): 2637-2650.

87 123. Whalley B, Azizi F. Rock glaciers and protalus landforms:Analogous forms and 923 ice sources on Earth and Mars. J Geophys Res. 2003; 108 :8032 doi:10.1029/2002JE001864 NO.

88 126. Julián A, Chueca J. Permafrost Distribution from BTS Measurements (Sierra de Telera, Central Pyrenees, Spain): Assessing the Importance of Solar Radiation in a Mid-elevation Shaded Mountainous Area. Permafr Periglacl Process. 2007; 18 :137-149.

89 127. Rico I, Magnin F, López-Moreno JI, Alonso E, Revuelto J, Serrano, E. First evidence of permafrost occurrence in a steep rock wall in the Pyrenees: The Vignemale North Face. In: Ruiz J et al. eds. Ambientes periglaciares: avances en su estudio, valoración patrimonial y riesgos asociados. Oviedo: Universidad de Oviedo; $2017: 87$. 
93490 128. Noetzli J, Gruber S, Kohl T, Salzmann N, Haeberli W. Three-dimensional 935 distribution and evolution of permafrost temperatures in idealized high-mountain 936 topography. J Geoph Res. 2007 :112:F02S13. doi: 101029/2006JF000545

93791 129. Lautridou JP, Francou B, Hall K. Present-day periglacial processes and 938 landforms in mountain areas. Permafr Periglacl Process. 1992 ;3(2) :93-101.

93992 132. Sellier D. Géomorphologie des versants quartzitiques en milieux froids: 940 l'exemple de montagnes d'Europe du Nord-Ouest. Thèse d'Etat, Paris: Université de Paris I; 2002.

94293 133. Kerguillec R. Étagements périglaciaires fonctionnels dans les massifs du 943 Dovrefjell et des Rondane (Norvège centrale). Environnements Périglaciaires. $944 \quad 2011 ; 17: 45-65$.

94594 134. Kerguillec R, Sellier D. Selection of geomorphosites in the Rondane National 946 Park (central Norway): landforms and popularization. Geomorphologie rel $947 \quad$ process environ. $2015 ; 21: 131-144$.

94895 17. Serrano E, Martínez de Pisón E, Agudo C. El medio periglaciar de alta montaña 949 en el Pirineo Central: aportaciones recientes. In: Procesos y formas periglaciares 950 en la alta montaña mediterránea. Teruel: Instituto de Estudios Turolenses; 2000 $951 \quad: 45-62$

95296 135. Fernandes M, Oliva M, Palma P, Lopes LF. Glacial stages and post-glacial 953 Environmental evolution in the Upper Garonne valley, Central Pyrenees. Sci Total $954 \quad$ Environ. 2017; 15 :584-585. doi: 10.1016/j.scitotenv.2017.01.209.

95597 136. Dobiński W. Permafrost of the Carpathian and Balkan Mountains, Eastern and 956 Southeastern Europe. Permafr Periglacl Process. 2005; 16: 395-398. 
98 137. Bodin X, Thibert E, Fabre D et al. Two decades of responses (1986-2006) to climate by the Laurichard rock glacier, French Alps. Permafr Periglacl Process. 2009; 20 (4): 331-344.

99 138. Gorbunov AP. Rock glaciers, kurums, glaciers and permafrost in the mountains of Turkey (Geographical review). Earth Cryosphere 2012; 16 (2): 3-8.

100 139. Oliva M, Gómez-Ortiz A, Salvador-Franch F et al. Inexistence of permafrost at the top of the Veleta peak (Sierra Nevada, Spain). Sci Total Environ. 2016; 550 :484-494.

101 140. Vieira G, Mora C, Ali F. New observations indicate the possible presence of permafrost in North Africa (Djebel Toubkal, High Atlas, Morocco). Cryosphere. 2017; 11 (4) :1691-1705.

\section{FIGURES:}

Figure 1. Location of massifs studied in the Pyrenees. 1, Infierno (3,175 $\mathrm{m}$ a.s.1.). 2, Monte Perdido (3,355 m a.s.1.). 3, Posets (3,375 m a.s.1.). 4, Maladeta (Aneto peak, 3,404 m a.s.1.).

Figure 2. Sketches of the areas studied with the main glacial and periglacial landforms.

Figure 3. Periglacial landforms distribution by altitude in the Pyrenees.

Figure 4. A, relation altitude/medium annual ground temperatures (MAGT) and B, altitude/medium March ground temperatures (MMGT). It is possible differentiate between the periglacial belts and in the case of MMGT the less correlation existent in each periglacial belt.

Figure 5. Altitudinal distribution of MMGT (A), MAGT (B) BTS measurements (C) and number of Freeze/Thaw cycles (D). SPB, supraperiglacial belts. MPB, middle periglacial belt. IPB, infraperiglacial belt.

Figure 6. Air and ground thermal regime (hydrologic year 2009-2010) on the debris lobe in Maladeta massif at 2920 m a.s.1.

Figure 7. Frozen ground distribution maps and isotherm altitude (red dotted line) of the areas studied.

Figure 8. A, altitudinal distribution of frozen ground in the areas studied. NFG, unfrozen ground. SFG, seasonal frozen ground. PoP, possible permafrost. PrP, probable 
996 permafrost. B, synthesis on altitude distribution of frozen ground and periglacial belts 997 (IP, infraperiglacial belt; MP, middle periglacial belt; SP supraperiglacial belt).

TABLES:

1000

1001 Table 1. Permafrost typology by factors.

1002 Table 2. Data used in this work

1003 Table 3. Periglacial processes and landforms analyzed in the Pyrenean high mountain 1004 area.

1005 Table 4. Studies on periglacial belts in the Pyrenees

1006

1007

1008

1009

1010

1011

1012

Table 1. Permafrost typology by factors

\begin{tabular}{|l|l|l|l|l|}
\hline \multicolumn{1}{|c|}{ Typology } & \multicolumn{2}{|c|}{ Permafrost classification } & \multicolumn{1}{c|}{ References } \\
\hline Thermal & $\begin{array}{l}\text { Cold } \\
\left(\text { MAGT }<-0,5^{\circ} \mathrm{C}\right. \\
\left.\text { never equal to } \sim 0^{\circ} \mathrm{C}\right)\end{array}$ & $\begin{array}{l}\text { Temperate } \\
\left(\mathrm{MAGT}=\sim 0^{\circ} \mathrm{C}\right)\end{array}$ & $\begin{array}{l}\text { Semi-temperate } \\
\left(\mathrm{MAGT}>-0,5^{\circ} \mathrm{C}\right. \\
\left.\text { occasionally values } \sim 0^{\circ} \mathrm{C}\right)\end{array}$ & Delaloyé, 2004 \\
\hline $\begin{array}{l}\text { Thermal rule- } \\
\text { based }\end{array}$ & $\begin{array}{l}\text { Probable } \\
\left(\text { MAGT }>-2^{\circ} \mathrm{C}\right)\end{array}$ & $\begin{array}{l}\text { Possible } \\
\left(\text { MAGT }-2 / 0^{\circ} \mathrm{C}\right)\end{array}$ & $\begin{array}{l}\text { Improbable } \\
\left(\text { MAGT }>1^{\circ} \mathrm{C}\right)\end{array}$ & Haeberli, 1985 \\
\hline Environmental & stable & metastable & instable & $\begin{array}{l}\text { Harris, 1986 } \\
\text { Oberman y Mazhitova, 2003 }\end{array}$ \\
\hline \multirow{3}{*}{$\begin{array}{l}\text { Spatial } \\
\text { (mapping) }\end{array}$} & Continuous & Discontinuous & Sporadic & Barsch,1978; Harris, 1986 \\
\cline { 2 - 5 } & Potential extensive & Potential local & Foen, 2005 \\
\cline { 2 - 5 } & $\begin{array}{l}\text { In rarely all } \\
\text { conditions }\end{array}$ & $\begin{array}{l}\text { Mostly in cold } \\
\text { conditions }\end{array}$ & $\begin{array}{l}\text { Only in very favourable } \\
\text { conditions }\end{array}$ & Boeckli et al. 2012 \\
\hline
\end{tabular}

1013

1014

1015 
Table 2. Data used in this work

\begin{tabular}{|c|c|c|c|c|c|c|c|c|c|c|c|c|c|c|c|}
\hline \multirow{2}{*}{\multicolumn{2}{|c|}{ Data }} & \multicolumn{3}{|c|}{ Infierno } & \multicolumn{3}{|c|}{ Monte Perdido } & \multicolumn{3}{|c|}{ Posets $^{59}$} & \multicolumn{3}{|c|}{ Maladeta } & \multicolumn{2}{|c|}{ TOTAL } \\
\hline & & $\mathrm{N}^{\circ}$ & Date & Altitude & $\mathrm{N}^{\circ}$ & date & Altitude & $\mathrm{N}^{\circ}$ & Date & Altitude & $\mathrm{N}^{\circ}$ & Date & Altitude & $\mathrm{N}^{\mathrm{o}}$ & Alt. \\
\hline \multicolumn{2}{|c|}{ Ground temperature } & 3 & $\begin{array}{l}2010- \\
2011\end{array}$ & $\begin{array}{l}2730 \\
2360 \\
\end{array}$ & 13 & $\begin{array}{l}2015- \\
2017\end{array}$ & $\begin{array}{l}3075 \\
2585 \\
\end{array}$ & 5 & $\begin{array}{l}2009- \\
2011\end{array}$ & $\begin{array}{l}2970 \\
2285 \\
\end{array}$ & 11 & $\begin{array}{l}2009- \\
2011\end{array}$ & $\begin{array}{l}2919 \\
2173 \\
\end{array}$ & 32 & $\begin{array}{l}3075 \\
2285 \\
\end{array}$ \\
\hline \multicolumn{2}{|c|}{ BTS measurements } & 119 & 2011 & $\begin{array}{l}2810 \\
2350\end{array}$ & $\begin{array}{c}56 \\
(154)\end{array}$ & 2016 & $\begin{array}{l}3075 \\
2585\end{array}$ & 72 & $2001^{59}$ & $\begin{array}{l}3155 \\
2620 \\
\end{array}$ & 80 & 2010 & $\begin{array}{l}3155 \\
2210\end{array}$ & 323 & $\begin{array}{l}3155 \\
2210\end{array}$ \\
\hline \multicolumn{2}{|l|}{ Mapping } & \multicolumn{12}{|c|}{ Geomorphological map, Thermal map, Permafrost distribution map. Frozen ground map 1/10,000 scale } & -- & -- \\
\hline \multirow[t]{2}{*}{$\begin{array}{l}\text { Indicators } \\
\text { landforms }\end{array}$} & SFG & \multicolumn{3}{|c|}{$\begin{array}{l}\text { Debris lobes } \\
\text { Patterned ground }\end{array}$} & \multicolumn{3}{|c|}{$\begin{array}{l}\text { Debris lobes } \\
\text { Patterned ground }\end{array}$} & \multicolumn{3}{|c|}{$\begin{array}{l}\text { Debris lobes } \\
\text { Patterned ground }\end{array}$} & \multicolumn{3}{|c|}{$\begin{array}{l}\text { Debris lobes } \\
\text { Patterned ground }\end{array}$} & \multicolumn{2}{|c|}{$\begin{array}{l}\text { Debris lobes } \\
\text { Patterned ground }\end{array}$} \\
\hline & Permafrost & \multicolumn{3}{|c|}{ Protalus lobe } & \multicolumn{3}{|c|}{$\begin{array}{l}\text { Protalus lobe } \\
\text { Frost mounds }\end{array}$} & \multicolumn{3}{|c|}{$\begin{array}{l}\text { Rock glaciers }{ }^{29,35,37,60,61} \\
\text { Protalus lobe } \\
\text { Frost mounds }\end{array}$} & \multicolumn{3}{|c|}{$\begin{array}{l}\text { Rock glaciers } \\
\text { Protalus lobe } \\
\text { Frost mounds }\end{array}$} & \multicolumn{2}{|c|}{$\begin{array}{l}\text { Rock glaciers } \\
\text { Protalus lobe } \\
\text { Frost mounds }\end{array}$} \\
\hline
\end{tabular}


Table 3. Periglacial processes and landforms analyzed in the Pyrenean high mountain.

\begin{tabular}{|c|c|c|c|c|c|c|c|c|c|c|c|c|c|c|c|c|}
\hline \multirow[t]{2}{*}{ Processes } & \multirow[t]{2}{*}{ Landforms } & \multicolumn{3}{|c|}{ Infierno } & \multicolumn{3}{|c|}{ Monte Perdido } & \multicolumn{3}{|c|}{ Posets } & \multicolumn{3}{|c|}{ Maladeta } & \multicolumn{2}{|c|}{ TOTAL } & \multirow[t]{2}{*}{ Indicators } \\
\hline & & $\mathbf{N}^{\mathbf{0}}$ & $\begin{array}{c}\text { Altitude } \\
\text { m }\end{array}$ & Or. & $\mathbf{N}^{0}$ & $\begin{array}{l}\text { Altitude } \\
\text { m }\end{array}$ & Or. & $\mathbf{N}^{\mathbf{0}}$ & $\begin{array}{l}\text { Altitude } \\
\text { m }\end{array}$ & Or. & $\mathbf{N}^{0}$ & $\begin{array}{c}\text { Altitude } \\
\text { m }\end{array}$ & Or. & $\mathbf{N}^{\mathbf{o}}$ & $\begin{array}{c}\text { Altitude } \\
\text { m }\end{array}$ & \\
\hline \multirow[t]{2}{*}{ Frost cracking } & $\begin{array}{l}\text { Debris talus } \\
\text { and cones }\end{array}$ & -- & $\begin{array}{l}3000 \\
2400\end{array}$ & $\begin{array}{c}\mathrm{N}, \\
\mathrm{S}, \mathrm{E}\end{array}$ & - & $\begin{array}{l}3040 \\
2555\end{array}$ & $\mathrm{~N}, \mathrm{~S}$ & - & $\begin{array}{l}3100 \\
2300\end{array}$ & $\begin{array}{l}\mathrm{N}, \\
\mathrm{W}, \\
\mathrm{E}\end{array}$ & -- & $\begin{array}{l}3050 \\
2200\end{array}$ & $\begin{array}{l}\text { E, N, W, } \\
\text { NW, NE }\end{array}$ & -- & $\begin{array}{l}3100 \\
2200\end{array}$ & Freeze-thaw \\
\hline & $\begin{array}{l}\text { Crest and } \\
\text { ridges }\end{array}$ & -- & $\begin{array}{l}3100 \\
2600\end{array}$ & -- & -- & $\begin{array}{l}2700 \\
3300\end{array}$ & -- & - & $\begin{array}{l}3300 \\
2900\end{array}$ & -- & -- & $\begin{array}{l}3200 \\
3000\end{array}$ & -- & -- & $\begin{array}{l}3300 \\
2600\end{array}$ & Freeze-thaw \\
\hline \multirow[t]{3}{*}{ Nivation } & $\begin{array}{l}\text { Nival } \\
\text { pavements }\end{array}$ & - & $\begin{array}{l}2900 \\
2400\end{array}$ & - & -- & $\begin{array}{l}2950 \\
2500\end{array}$ & -- & -- & $\begin{array}{l}3100 \\
2600\end{array}$ & -- & -- & $\begin{array}{l}2700 \\
2470\end{array}$ & -- & -- & $\begin{array}{l}3100 \\
2400\end{array}$ & Freeze-thaw \\
\hline & $\begin{array}{l}\text { Nivokarst } \\
\text { landforms }\end{array}$ & -- & -- & -- & $\begin{array}{ll}-- \\
\end{array}$ & $\begin{array}{c}3100 \\
2500^{*}\end{array}$ & -- & -- & -- & -- & -- & -- & $\begin{array}{ll}-- \\
\end{array}$ & -- & -- & No frost \\
\hline & $\begin{array}{l}\text { Protalus } \\
\text { ramparts }\end{array}$ & 7 & $\begin{array}{l}2690 \\
2450\end{array}$ & $\begin{array}{l}\mathrm{N}, \mathrm{E} \\
\mathrm{NE},\end{array}$ & - & -- & -- & 1 & $\begin{array}{l}2750 \\
2700\end{array}$ & NW & 2 & $\begin{array}{l}3000 \\
2970\end{array}$ & $\mathrm{~N}$ & 10 & $\begin{array}{l}3000 \\
2450\end{array}$ & No frost \\
\hline \multirow[t]{3}{*}{$\begin{array}{l}\text { Mass } \\
\text { movement }\end{array}$} & Debris flow & 16 & $\begin{array}{l}2500 \\
2450\end{array}$ & $\mathrm{NE}$ & 3 & $\begin{array}{l}2700 \\
2500\end{array}$ & & 16 & & E, N & 3 & $\begin{array}{l}2500 \\
2300\end{array}$ & & 38 & $\begin{array}{l}2700 \\
2300\end{array}$ & No frost \\
\hline & $\begin{array}{l}\text { Solifluction } \\
\text { lobes }\end{array}$ & -- & $\begin{array}{l}2400 \\
2200\end{array}$ & -- & - & - & - & - & $\begin{array}{l}2600 \\
2200\end{array}$ & -- & - & $\begin{array}{l}2500 \\
2100\end{array}$ & - & - & $\begin{array}{l}2600 \\
2100\end{array}$ & Freeze-thaw \\
\hline & Terracettes & -- & $\begin{array}{l}2450 \\
2200\end{array}$ & - & - & $\begin{array}{l}2650 \\
2490\end{array}$ & $\mathrm{~N}, \mathrm{~S}, \mathrm{E}$ & - & $\begin{array}{l}2700 \\
2200\end{array}$ & $\begin{array}{l}\text { E, } \\
W\end{array}$ & - & $\begin{array}{l}2650 \\
2200\end{array}$ & $\mathrm{~N}, \mathrm{~S}$ & - & $\begin{array}{l}2700 \\
2200\end{array}$ & Freeze-thaw \\
\hline \multirow{3}{*}{$\begin{array}{l}\text { Gelifluction } \\
\text { and frozen } \\
\text { ground creep }\end{array}$} & Debris lobes & - & $\begin{array}{l}2700 \\
2500\end{array}$ & - & 8 & $\begin{array}{l}3030 \\
2520 \\
\end{array}$ & $\begin{array}{c}\text { N, NE, } \\
N W, S E\end{array}$ & 3 & $\begin{array}{l}2900 \\
2650 \\
\end{array}$ & $\begin{array}{l}\text { W, } \\
\text { E }\end{array}$ & -- & $\begin{array}{l}2920 \\
2700 \\
\end{array}$ & $\mathrm{~N}, \mathrm{E}$ & 11 & $\begin{array}{l}3030 \\
2500 \\
\end{array}$ & SFG \\
\hline & Rock glaciers & 1 & $\begin{array}{l}2730 \\
2590\end{array}$ & $\mathrm{NW}$ & - & - & - & 2 & $\begin{array}{l}3050 \\
2780\end{array}$ & $\begin{array}{l}\mathrm{N}, \\
\mathrm{NE}\end{array}$ & 1 & $\begin{array}{l}3110 \\
2910\end{array}$ & & 4 & $\begin{array}{l}3100 \\
2590\end{array}$ & Permafrost \\
\hline & $\begin{array}{l}\text { Protalus } \\
\text { lobes }\end{array}$ & 1 & $\begin{array}{l}2700 \\
2680\end{array}$ & $\mathrm{~N}$ & 1 & $\begin{array}{l}2900 \\
2850\end{array}$ & $\mathrm{~N}$ & 4 & $\begin{array}{l}3000 \\
2775\end{array}$ & $\begin{array}{c}\mathrm{N}, \\
\mathrm{W} \\
\mathrm{NW}\end{array}$ & 2 & $\begin{array}{l}2960 \\
2750\end{array}$ & NW, NE & 8 & $\begin{array}{l}3000 \\
2680\end{array}$ & Permafrost \\
\hline \multirow[t]{2}{*}{ Cryoturbation } & Frost mounds & -- & -- & -- & 4 & $\begin{array}{l}2850 \\
2760\end{array}$ & -- & $\begin{array}{l}10 \\
(6)\end{array}$ & $\begin{array}{l}3050 \\
2670\end{array}$ & -- & $\begin{array}{c}7 \\
(2)\end{array}$ & $\begin{array}{l}2920 \\
2900\end{array}$ & -- & 21 & $\begin{array}{l}3050 \\
2670\end{array}$ & Permafrost \\
\hline & $\begin{array}{l}\text { Patterned } \\
\text { grounds }\end{array}$ & - & $\begin{array}{l}2600 \\
2430\end{array}$ & - & $\begin{array}{l}20 \\
(5)\end{array}$ & $\begin{array}{l}2790 \\
2530\end{array}$ & -- & $\begin{array}{c}36 \\
\text { (11) }\end{array}$ & $\begin{array}{l}3050 \\
2800\end{array}$ & -- & (2) & $\begin{array}{l}2900 \\
2500\end{array}$ & -- & $\sim 60$ & $\begin{array}{l}3050 \\
2530\end{array}$ & SFG \\
\hline
\end{tabular}

Or., Orientation. SFG, seasonally frozen ground. 
Table 4. Studies on periglacial belts in the Pyrenees

\begin{tabular}{|c|c|c|c|c|c|c|}
\hline Authors & Area & \multicolumn{2}{|c|}{ Periglacial belts } & Altitude & Periglacial & Frozen Ground \\
\hline \multirow{3}{*}{$\begin{array}{l}\text { Serrano et } \\
\text { al. } 2000\end{array}$} & \multirow{3}{*}{$\begin{array}{l}\text { Central } \\
\text { Southern } \\
\text { Pyrenees }\end{array}$} & $\begin{array}{l}\text { Supra- } \\
\text { periglacial }\end{array}$ & Glacionival & $\begin{array}{c}>3000- \\
3100\end{array}$ & $\begin{array}{l}\text { Frost cracking } \\
\text { Gelifluction } \\
\text { Cryoturbation }\end{array}$ & $\begin{array}{l}\text { Continuous } \\
\text { permafrost }\end{array}$ \\
\hline & & Periglacial & Cryonival & $\begin{array}{c}\sim 3100 \\
2600-2700\end{array}$ & $\begin{array}{l}\text { Frost cracking } \\
\text { Gelifluction }\end{array}$ & $\begin{array}{l}\text { Disc. permafrost } \\
\text { Cont.permafrost }\end{array}$ \\
\hline & & $\begin{array}{l}\text { Infra- } \\
\text { periglacial }\end{array}$ & $\begin{array}{l}\text { Nivo- } \\
\text { periglacial }\end{array}$ & $\begin{array}{c}2600-2700 \\
\sim 2100\end{array}$ & $\begin{array}{l}\text { Nivaton } \\
\text { Solifluction } \\
\text { Frost cracking } \\
\text { Gelifluction }\end{array}$ & $\begin{array}{l}\text { Sporadic } \\
\text { permafrost }\end{array}$ \\
\hline \multirow{4}{*}{$\begin{array}{l}\text { Feuillet, } \\
2010\end{array}$} & \multirow{4}{*}{$\begin{array}{l}\text { Central } \\
\text { Northern } \\
\text { Pyrenees }\end{array}$} & \multirow{3}{*}{\multicolumn{2}{|c|}{ Atlantic mountain periglacial }} & $>2850$ & -- & Con. permafost \\
\hline & & & & $>2650$ & Cryoturbation & $\begin{array}{l}\text { Disc. permafrost } \\
\text { NFG }\end{array}$ \\
\hline & & & & $\begin{array}{l}2620 \\
2300\end{array}$ & $\begin{array}{l}\text { Gelifluction } \\
\text { Cryoturbation }\end{array}$ & $\begin{array}{l}\text { SFG } \\
\text { NFG }\end{array}$ \\
\hline & & \multicolumn{2}{|l|}{ Lower limit } & $2250-2300$ & Solifluction & -- \\
\hline \multirow{4}{*}{$\begin{array}{l}\text { González- } \\
\text { García, } \\
2013\end{array}$} & \multirow{4}{*}{$\begin{array}{l}\text { Central } \\
\text { Southern } \\
\text { Pyrenees }\end{array}$} & $\begin{array}{l}\text { Supra- } \\
\text { periglacial }\end{array}$ & $\begin{array}{l}\text { Glacionival } \\
>3100\end{array}$ & $\begin{array}{c}\sim 3400 \\
3000-3100\end{array}$ & $\begin{array}{l}\text { Nivaton } \\
\text { Frost cracking }\end{array}$ & $\begin{array}{l}\text { Prob. } \\
\text { permafrost } \\
>2900\end{array}$ \\
\hline & & Periglacial & Cryonival & $2600-2700$ & $\begin{array}{l}\text { Nivaton } \\
\text { Solifluction } \\
\text { Frost cracking } \\
\text { Gelifluction } \\
\text { Cryoturbation }\end{array}$ & $\begin{array}{l}\text { Poss. permafrost } \\
>2800 \text { m a.s.l. } \\
\text { Prob. } \\
\text { permafrost } \\
>2900 \text { m a.s.l. }\end{array}$ \\
\hline & & \multirow[t]{2}{*}{$\begin{array}{l}\text { Infra- } \\
\text { periglacial }\end{array}$} & $\begin{array}{l}\text { Nivo- } \\
\text { periglacial }\end{array}$ & $\begin{array}{l}\sim 2600 \\
\sim 2300\end{array}$ & $\begin{array}{l}\text { Nivation } \\
\text { Solifluction } \\
\text { Gelifluction }\end{array}$ & $\begin{array}{l}\text { Spor. } \\
\text { Permafrost }\end{array}$ \\
\hline & & & Nival & $\begin{array}{l}\sim 2300 \\
\sim 2000\end{array}$ & $\begin{array}{l}\text { Solifluction } \\
\text { Runoff } \\
\text { Nivation }\end{array}$ & Seasonal ice \\
\hline \multirow{3}{*}{$\begin{array}{l}\text { Fernandes } \\
\text { et al. } \\
2017\end{array}$} & \multirow{3}{*}{$\begin{array}{l}\text { Upper } \\
\text { Garona } \\
\text { bassin }\end{array}$} & \multicolumn{2}{|c|}{ Periglacial/cryonival } & $\begin{array}{l}\sim 2800 \\
\sim 2300\end{array}$ & $\begin{array}{l}\text { Cryoturbation } \\
\text { Solifluction } \\
\text { Talus slopes } \\
\text { Nivation }\end{array}$ & - \\
\hline & & \multicolumn{2}{|l|}{ Nival } & $\begin{array}{l}2300 \\
\sim 1900\end{array}$ & $\begin{array}{l}\text { Nivaton } \\
\text { Cryoturbation } \\
\text { Solifluction } \\
\text { Talus slopes }\end{array}$ & -- \\
\hline & & \multicolumn{2}{|l|}{ Subnival } & $\begin{array}{l}\sim 1900 \\
\sim 1500\end{array}$ & $\begin{array}{l}\text { Peat } \\
\text { development } \\
\text { Talus slopes }\end{array}$ & -- \\
\hline
\end{tabular}

Cont. permafrost, continuous permafrost; Disc. permafrost, discontinuous permafrost; Spor. permafrost.sporadic permafost; 